\title{
RMetS
}

\section{On the relationship between water vapour field evolution and the life cycle of precipitation systems}

\author{
J. Van Baelen, ${ }^{a \star}$ M. Reverdy, ${ }^{a}$ F. Tridon, ${ }^{a}$ L. Labbouz, ${ }^{a}$ G. Dick, ${ }^{b}$ M. Bender ${ }^{b}$ and M. Hagen ${ }^{c}$ \\ ${ }^{a}$ Laboratoire de Météorologie Physique, CNRS - Université Blaise Pascal, Clermont-Ferrand, France \\ ${ }^{\mathrm{b}}$ Helmholtz-Centre Potsdam, GFZ, German Research Centre for Geosciences, Potsdam, Germany \\ ${ }^{\mathrm{c}}$ Deutsches Zentrum für Luft- und Raumfahrt (DLR), Oberpfaffenhofen, Germany \\ ${ }^{\star}$ Correspondence to: J. Van Baelen, LaMP, Université Blaise Pascal, 24 Avenue des Landais, PO Box 80026, 63171 Aubière \\ CEDEX, France. E-mail: j.vanbaelen@opgc.univ-bpclermont.fr
}

In this work, we investigate the relationship between the structure and evolution (from initiation to decay) of precipitation systems, and the associated water vapour distributions during the COPS (Convective Orographically-induced Precipitation Study). This international field campaign took place over an area from the Vosges to the Black Forest Mountains, across the Rhine Valley, in summer 2007. In particular, we consider water vapour retrieval through GPS integrated water vapour 2D maps and $3 \mathrm{D}$ tomography, and compare these to precipitation systems observed with the ground-based C-band POLDIRAD weather radar.

We have demonstrated the predominant role of water vapour as a precursor to convective initiation for local convective cell generation. Water vapour accumulation on the crest of the orography is associated with ridge convection, while water vapour passing over the mountain top and creating valley outflows generates lee-side convection, often triggered by a small hill positioned within or close to the valley exit, or by a local convergence with the water vapour field over the plain.

We have also noted that frontal systems seem to develop preferentially where the largest amount of water vapour is available. Likewise, in the case of frontal systems, well-formed synoptic-scale storms are associated with high water vapour signatures, while weaker systems with embedded convection appear to trail high water vapour areas where the convective element is associated with local water vapour depletion. This latter aspect could be the signature of convective cloud formation, when water vapour is transferred into liquid water, before the onset of precipitation. Copyright (c) 2011 Royal Meteorological Society

Key Words: COPS; weather radar; orography; GPS

Received 4 March 2010; Revised 18 December 2010; Accepted 11 January 2011; Published online in Wiley Online Library 11 February 2011

Citation: Van Baelen J, Reverdy M, Tridon F, Labbouz L, Dick G, Bender M, Hagen M. 2011. On the relationship between water vapour field evolution and the life cycle of precipitation systems. Q. J. R. Meteorol. Soc. 137: 204-223. DOI:10.1002/qj.785

1. Introduction

The COPS (Convective and Orographically-induced Precipitation Study) international field campaign took place from June to August in 2007, in southwest Germany and northeast
France, across the Rhine Valley from the Vosges Mountains to the Black Forest Mountains (Figure 1). The overall objective of COPS is to improve the quantitative precipitation forecast (QPF) skill of numerical weather prediction (NWP) models over mid-range mountainous terrain. Hence, the 


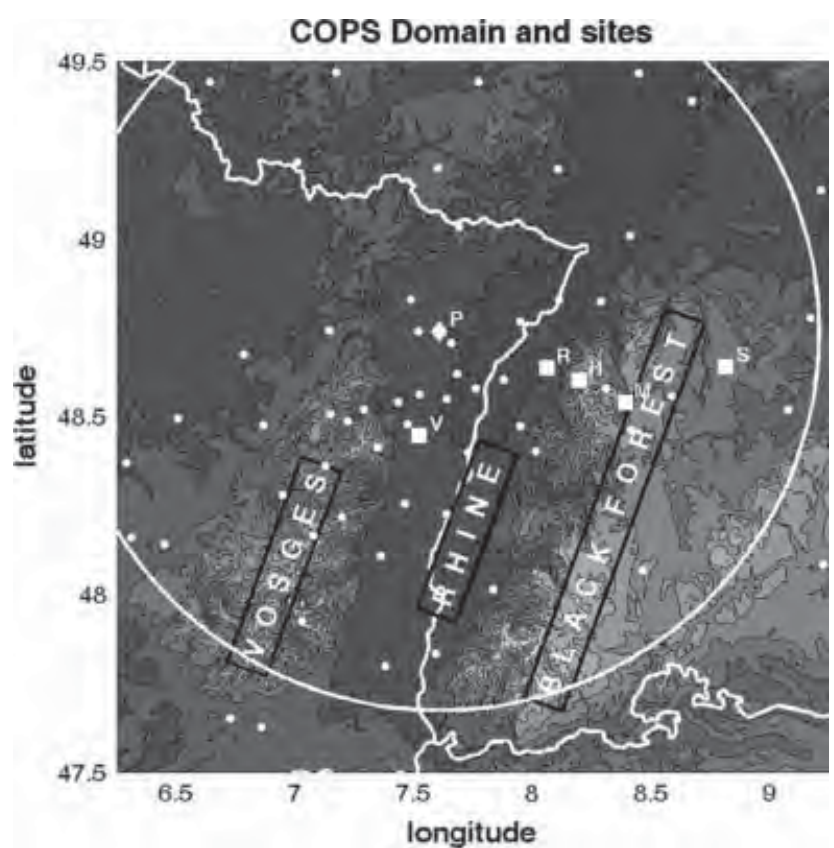

Figure 1. The COPS campaign domain with the GPS stations network (white dots), the POLDIRAD (P) weather radar location (white diamond) with its $120 \mathrm{~km}$ radius field-of-view circle, and the instrumentation supersites (white squares) from west to east: Vosges low mountain site (V), Rhine valley site $(\mathrm{R})$, Hornisgrinde mountain site $(\mathrm{H})$, Murg valley site $(\mathrm{M})$, and Deckenpfronn site near Stuttgart (S). The main orographic features are also indicated: the Vosges mountains to the west, the Rhine Valley in the centre, and the Black Forest mountains to the east.

research interests of the campaign deal primarily with the study of the meteorological conditions and forcing mechanisms leading to convective initiation, with the monitoring of the precipitation life cycle, and with the analysis of the role played by orography on initiation and development of the precipitation system. To achieve this goal, a large set of in situ and remote-sensing instrumentation was deployed over a series of supersites at selected locations across the domain of interest, while numerous operational and research models were run operationally to assess their performances during different events observed during Intensive Operation Periods (IOPs).

Wulfmeyer et al. (2008) and Wulfmeyer et al. (2011) provide more details on the campaign background, on its implication for other international efforts, on the strategy of the observations and campaign implementation, on the description and characteristics of the instruments deployed and on some preliminary results. Likewise, reports on results and ongoing research within the framework of COPS can be found in Kottmeier et al. (2008) and in the various papers of this special issue.

The scientific scope of the present article tackles only a small aspect of this ambitious programme. It focuses on the preliminary investigation of the relationship that can be found between the precipitation system structure, intensity and dynamics, from initiation to decay, and the associated water vapour field distribution and evolution. In particular, we will consider water vapour retrieval exclusively through Global Positioning System (GPS) tomography and precipitation systems monitoring with ground-based radars only. At this point we easily acknowledge that this provides only a partial view of the problem, while further investigations using increased resolution and other means of measurement are still in progress. Nonetheless, the current work deals with the role of water vapour as a precursor and/or tracer of precipitation activity, with the effect of orography on the water vapour field distribution and evolution, with the necessity (or not?) of water vapour convergence to start convective activity or foster precipitation system enhancement, and also with the capability of GPS tomography to provide an adequate tool to study such problems.

In section 2, we will present the experimental set-up deployed during the COPS campaign that provided the data used in this study: the GPS network, the POLDIRAD (Polarimetric Diversity Doppler Radar) C-band ( $~ 5 \mathrm{GHz})$ research radar and the French supersite UHF $(\sim 1.2 \mathrm{GHz})$ wind profiler. In section 3 , we will describe the GPS signal processing as well as the tomography algorithm used and discuss its scope and current limitations. In section 4, we will focus on particular IOP cases where precipitation events were monitored with POLDIRAD to study their associated GPS-retrieved water vapour field and its evolution before and during the rain. Finally, in section 5, we will offer some preliminary conclusions and comments, and outline further work and developments.

\section{The experimental set-up}

For more than a decade, the GPS has proven to be an autonomous, all-weather and continuous system for the measurement of atmospheric water vapour (Bevis et al., 1992, 1994; Businger et al., 1996). With such a technique, one can retrieve the Integrated Water Vapour (IWV) representative of the atmospheric column above the GPS station with good accuracy (Tregoning et al., 1998; Van Baelen et al., 2005; Wang et al., 2007). Furthermore, when a dense network of GPS stations exists, GPS can be used to perform tomography in order to retrieve the three-dimensional distribution of water vapour density (Flores et al., 2000, 2001; Gradinarsky and Jarlemark, 2004; Champollion et al., 2005; Reverdy et al., 2009).

Therefore, as part of the COPS instrumental set-up, the existing networks of GPS stations in France and Germany were enhanced with temporary stations so that an average separation of less than $40 \mathrm{~km}$ between GPS stations over the entire COPS domain was achieved (see also Zus et al., 2008, and Schwitalla et al., 2011. Furthermore, a denser segment of stations separated by about $10 \mathrm{~km}$ was also created from the crest of the Vosges to the Black Forest, across the Rhine Valley. This segment was approximately aligned with the different supersites of the campaign. Figure 1 shows the resulting network of GPS stations that provided data for the present work. The stations within the network had a variety of altitudes, some installed in the plains or valleys and others on the mountains to offer a homogenous representation of the varying terrain of the region. Within the network, most stations stood between 136 and $912 \mathrm{~m}$ above mean sea level (amsl), with the exception of the station installed at the Hornisgrinde supersite at $1213 \mathrm{~m}$ amsl. For all GPS stations, data were recorded with a $30 \mathrm{~s}$ sampling interval and an elevation cut-off angle of $5^{\circ}$.

In order to relate the water vapour field evolution and patterns retrieved through GPS tomography to the different characteristics of precipitating systems, we used weather radar observations to monitor the convective initiation, the onset of precipitation and the subsequent development of those precipitation systems. 

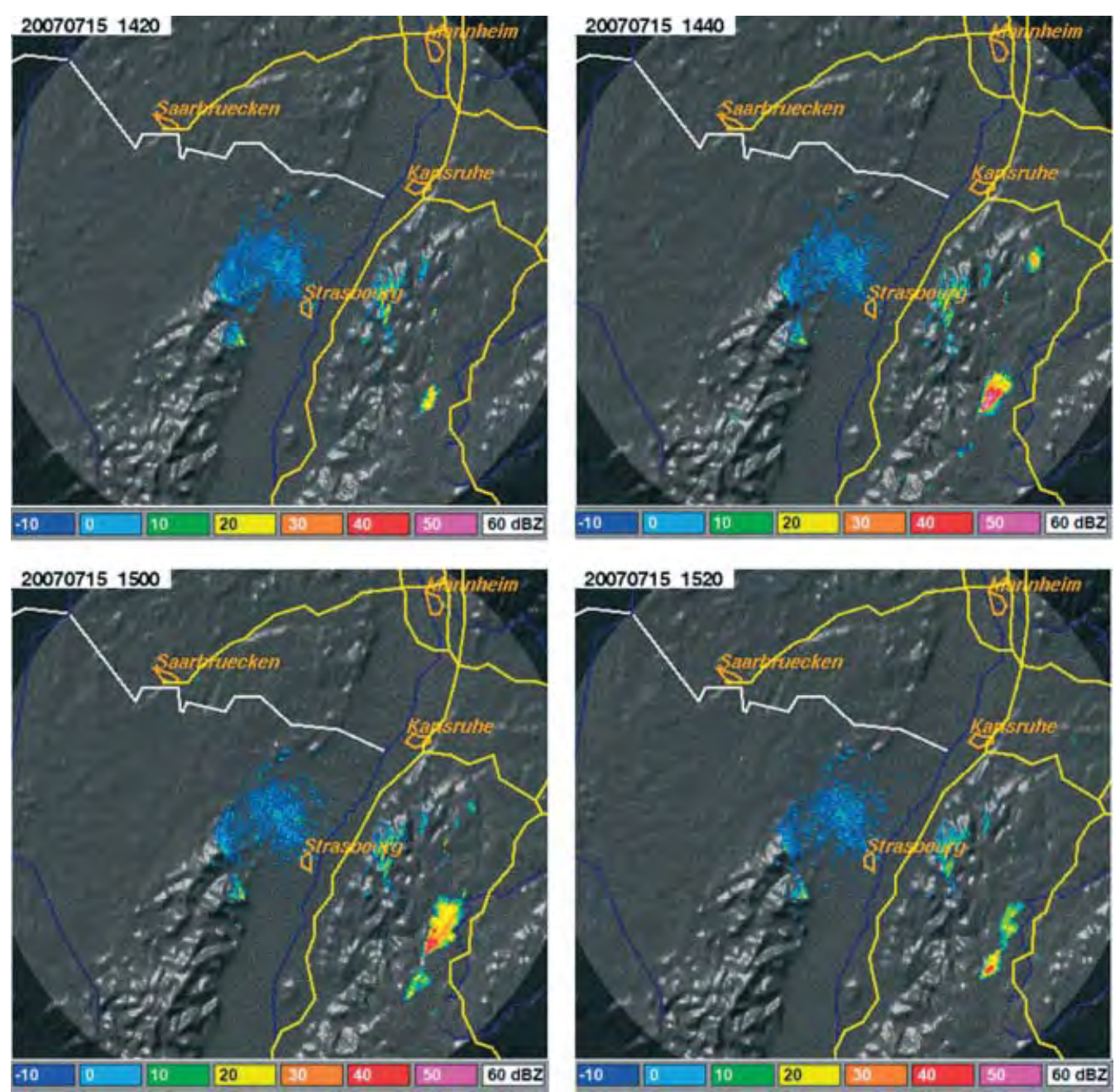

Figure 2. POLDIRAD reflectivity PPI observations of the isolated heavy precipitation cell on 15 July 2007 (IOP $8 \mathrm{~b}$ ) at $1420,1440,1500$, and 1520 UTC The colour scale indicates the reflectivity from -10 to $60 \mathrm{dBZ}$. This figure is available in colour online at wileyonlinelibrary.com/journal/qj

The polarimetric C-band Doppler research radar POLDIRAD (Schroth et al., 1988) of DLR (Deutsches Zentrum für Luft- und Raumfahrt) was deployed for three months in the foothills of the Vosges Mountains at Waltenheim-sur-Zorn at $260 \mathrm{~m}$ amsl, about $20 \mathrm{~km}$ northwest of Strasbourg. Its location was about $100 \mathrm{~m}$ above the floor of the Rhine Valley, providing an undisturbed overview over the Rhine Valley, the Black Forest and the Vosges in order to complement the existing operational weather radars of Deutscher Wetterdienst, Météo-France and MeteoSwiss. During IOPs, volume PPI (Plan Position Indicator) scans were performed up to $120 \mathrm{~km}$ range every 10 to $20 \mathrm{~min}$.

For the COPS campaign, the Vosges supersite also included a UHF boundary-layer wind profiler fielded by the CNRM (Centre National de Recherches Météorologiques) of Météo-France in the plains a few km east of the Vosges foothills (Richard et al., 2009). This radar provides vertical profiles of wind amplitude and direction with $75 \mathrm{~m}$ height resolution from $150 \mathrm{~m}$ above the ground up to about $3 \mathrm{~km}$ and with a 15 min time resolution in its high-resolution mode. However, this wind profiler was only deployed during the month of July.

Figure 1 indicates the locations of the POLDIRAD radar and of the French supersite where the UHF radar was installed.

\section{GPS processing and tomography for water vapour field retrieval}

The GPS data collected throughout the campaign were processed with the EPOS (Earth Parameter and Orbit System) software package developed at the GFZ (GeoForschungZentrum, Potsdam, Germany). (Gendt et al., 2001, 2004, give detailed descriptions of EPOS.) Globally, the EPOS software can estimate different parameters from GPS observations. It can be used for various applications by configuring the processing appropriately, for example IGS (International GNSS Service) data processing, GPS campaign and GPS meteorology. For GPS meteorological applications, data can be processed in network mode and Precise Point Positioning (PPP) mode (Zumberge et al., 1997) with the EPOS software. In PPP mode, satellite-related parameters, i.e. satellite orbits and clocks, earth rotation parameters, etc., are all assumed to be well-known, so there are no common unknown parameters among stations. Consequently, the data can be processed station by station. This enables data for a large number of GPS stations observed simultaneously, e.g. from a dense network, to be processed independently on different processors. In order to obtain the satellite-related parameters, a global network should be processed in a fashion similar to the generation of the IGS ultra-rapid or rapid products which can usually only be carried out by IGS Analysis Centres like 

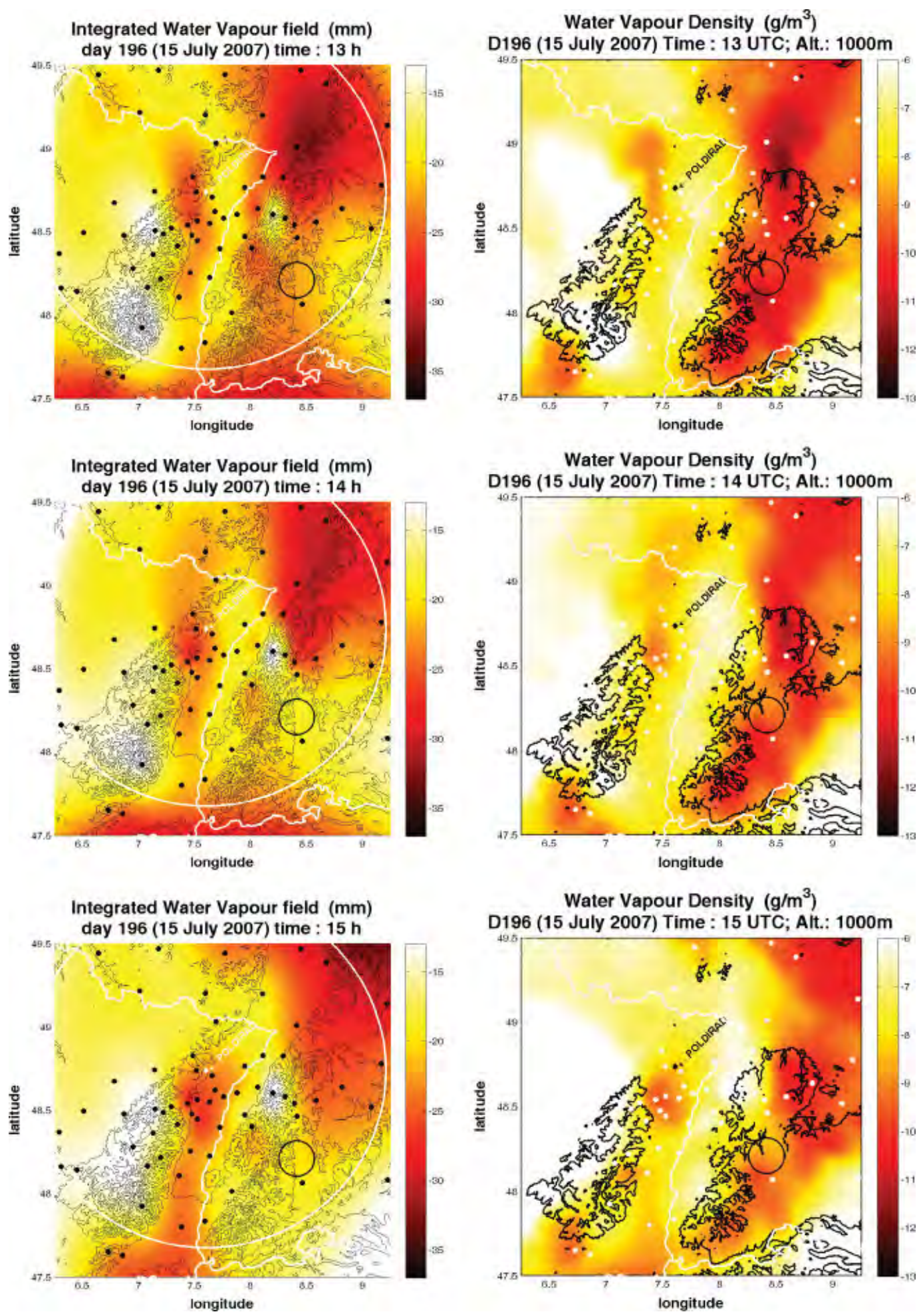

Figure 3. GPS IWV 2D fields (left column), and tomography horizontal water vapour density fields at the $1000 \mathrm{~m}$ height layer (right column) from 13:00 to 15:00 UTC on July 152007 (IOP 8b). The IWV scale goes from 13 to $37 \mathrm{~mm}$ (from light to dark) and the water vapour density scale goes from 6 to $13 \mathrm{~g} \mathrm{~m}^{3}$ (from light to dark). The black circle indicates the area of convective activity seen on the radar display of Figure 2. This figure is available in colour online at wileyonlinelibrary.com/journal/qj

GFZ. Here for regional GPS meteorological applications, the involvement of several stations around the network will improve the parameters needed to be fixed in PPP data processing. EPOS is based on a least-squares adjustment of zero-differenced phase and range observations. The advantage of using zero-differenced observations is that ray path residuals required to construct the slant total delays (STDs) are available directly in the form of observation residuals.
For precise positioning, the signal delay due to the neutral atmosphere needs to be modelled. The zenith total delay (ZTD) and atmospheric gradients in north-south and east-west directions are therefore estimated together with the geodetic parameters. The STD along a given signal path can be approximated by applying the global mapping function (GMF; Boehm et al., 2006) or the Niell mapping function (Niell, 1996) to the ZTDs while the 

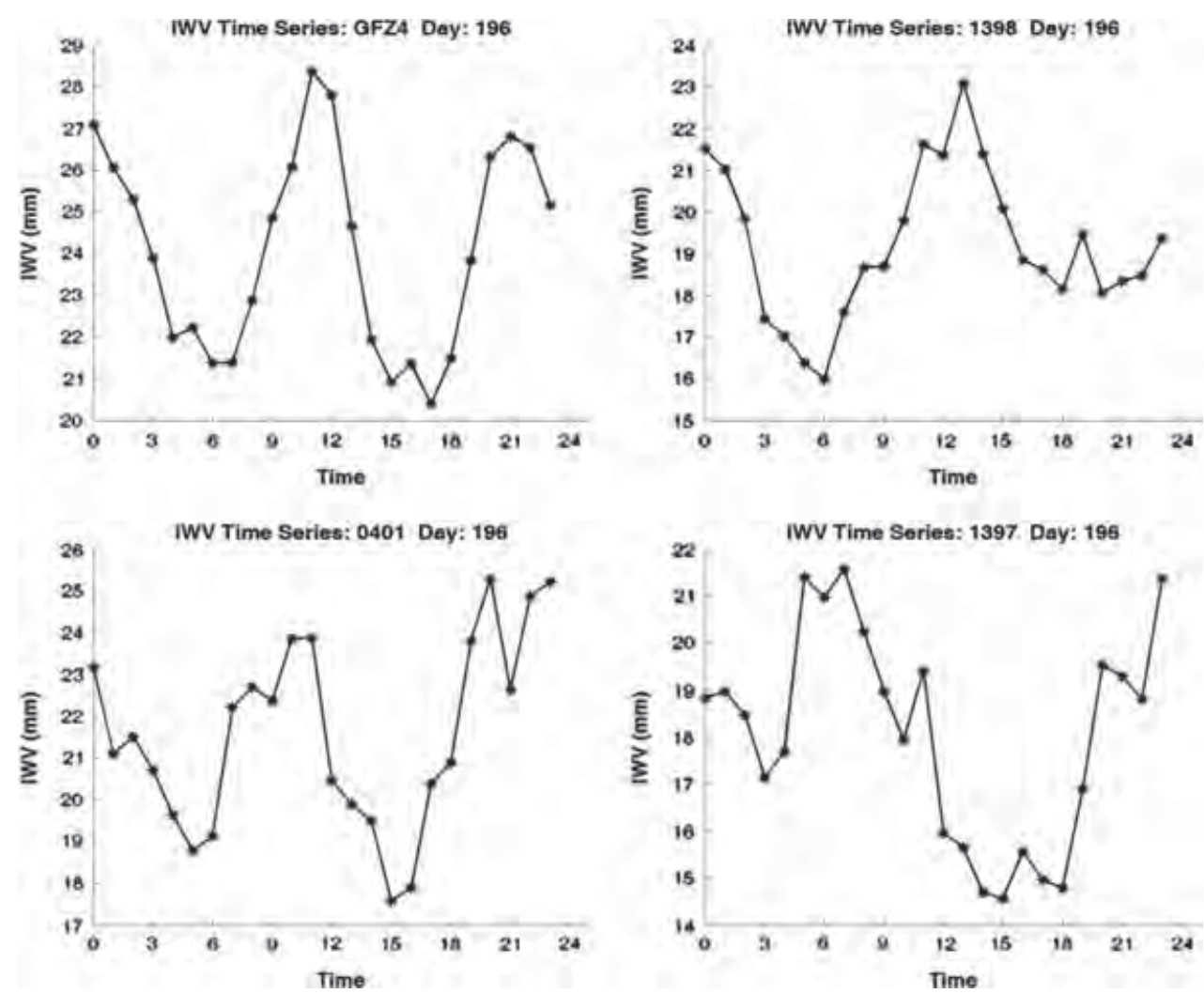

Figure 4. IWV time series for 15 July 2007 (IOP 8b: day 196) for the four GPS stations around the area of convective activity at 1500 UTC in the Black Forest (black circle on the Figure 3). The plots are arranged to roughly correspond to their positions relative to the convective activity (i.e. the top left plot is to the northwest).

horizontal atmospheric inhomogeneity is provided by the gradients. Hence, contributions to the path delay which cannot be described by this model go into the ray path residuals. To obtain more precise atmospheric parameters, the station coordinates and several other parameters are fixed in the troposphere PPP run. Due to the reduced number of free parameters, the residuals are dominated by unmodelled atmospheric contributions while the impact of other uncertainties is minimised. Under these assumptions the STD is given by

$$
\begin{aligned}
S T D= & m_{\mathrm{h}} Z H D \\
& +m_{\mathrm{w}}\left[Z W D+\cot \varepsilon\left(G_{\mathrm{N}} \cos \varphi+G_{\mathrm{E}} \sin \varphi\right)\right]+\delta,
\end{aligned}
$$

where $Z H D$ and $Z W D$ are the zenith hydrostatic and wet delays, respectively, $m_{\mathrm{h}}$ and $m_{\mathrm{w}}$ are the hydrostatic and the wet mapping functions, $G_{\mathrm{N}}$ and $G_{\mathrm{E}}$ are the delay gradient parameters in the northern and eastern directions, $\varepsilon$ is the elevation, $\varphi$ is the geographic latitude and $\delta$ is the post-fit phase residual. In this automated signal analysis, the hydrostatic and the wet contributions to the ZTD are separated using the Saastamoinen (1972) model and climatological data. The zenith delays and mapping functions alone lead to STDs which are rotationally symmetric. The information about spatial atmospheric structures is mainly provided by the residuals, and to a minor degree by the gradients.

The errors of the GPS observations and the rather complicated processing chain are difficult to estimate. Therefore, it is important to validate the ZTD and STD estimates with independent observations (Duan et al., 1996; Ware et al., 1997; Liljegren et al., 1999; Braun et al., 2003, Van Baelen et al., 2005) or models (Ha et al., 2003; Liu amd
Xue, 2006). Intercomparison studies with water vapour radiometers and weather models show a STD bias below $1 \mathrm{~mm}$ for elevations greater than $30^{\circ}$ and below $1.5 \mathrm{~mm}$ for elevations down to $5^{\circ}$ (Bender et al., 2008).

For meteorological applications, the availability and the temporal resolution of these data is important. Currently, GPS raw observations with a sampling rate of $2.5 \mathrm{~min}$ are processed on an hourly basis and the results are available in near-real time. A $12 \mathrm{~h}$ sliding window with $1 \mathrm{~h}$ steps is used to process the tropospheric parameters for the most recent hour. Gradients are estimated once per hour, and ZTDs for 15 min intervals. STDs are retrieved with the full sampling rate of $2.5 \mathrm{~min}$ by adjusting the corresponding residuals for each individual satellite-receiver link. Each day, 96 ZTDs and about 4500 STDs are available per station.

For case-studies, when an ensemble of GPS stations is available over a limited area, the transmission rays from satellites to receivers can interleave together and tomography inversion will allow the computation of the three-dimensional distribution of the atmospheric water vapour. Indeed, if one defines the volume above the GPS network as an ensemble of atmospheric boxes, called voxels, these voxels will be traversed by various individual rays. Hence, in this case, the STDs are the GPS observables used for tomography, but first they have to be converted into slant-integrated water vapour (SIWV) which corresponds to the humidity-induced part of the tropospheric delay in the propagation from the satellite to the receiver. To derive the SIWVs from the STDs, one has first to subtract the corresponding hydrostatic component. For precise meteorological analysis, this step requires a knowledge of the pressure field, determined from meteorological surface stations for example, to calculate the hydrostatic component 

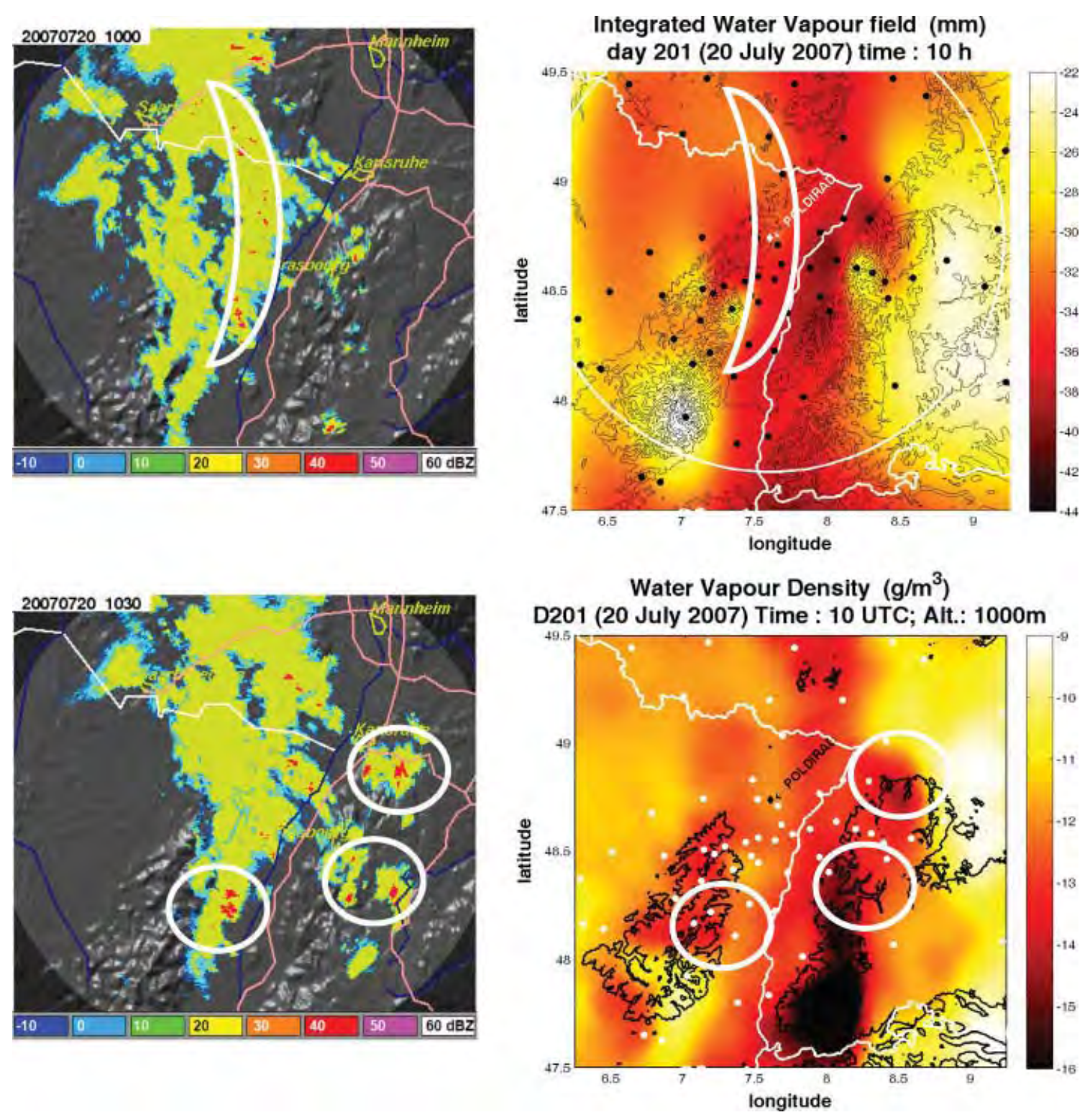

Figure 5. POLDIRAD reflectivity PPI observations on 20 July 2007 (IOP 9c) at 1000 UTC and 1030 UTC (left column), and GPS IWV field (top right panel) and tomography horizontal water vapour density field for the $1000 \mathrm{~m}$ (bottom right panel) height layer at 1000 UTC on July 202007 (IOP 9c). The radar reflectivity scale goes from -10 to $60 \mathrm{dBZ}$. The IWV scale from 22 to $44 \mathrm{~mm}$ (from light to dark), and the water vapour density scale from 9 to $16 \mathrm{~g} \mathrm{~m}^{-3}$ (from light to dark). Areas outlined in white are discussed in the text. This figure is available in colour online at wileyonlinelibrary.com/journal/qj

along each ray, using Saastamoinen's (1972) formulation, as it propagates through the atmospheric volume above the analysis domain. Then, following relations defined by Emardson and Derks (1999) that make use of the atmospheric temperature, the resulting slant wet delay (SWD) can be converted into SIWV. Once these SIWV are determined, they are distributed among the different voxels of the analysis domain, according to the length of their path within each voxel, and weighted by the vertical distribution of the standard atmosphere (i.e. more weight to the lower levels where water vapour is more abundant). These lengths are essential to create the linear operator of the tomography. We consider that there is no water vapour above an altitude of $12 \mathrm{~km}$. Also, when one of the rays quits the analysis domain below $12 \mathrm{~km}$ through one of the side boundaries, only its proportional path within the domain is accounted for, since SIWV are integrated values.

Depending on the GPS station and satellite geometry, some voxels will contain data (one or multiple rays), especially in the highest layers of the atmosphere, while some others might not, in particular in the lowest layers of the grid. Thus, we face a partially determined problem that can be expressed in the equation (Tarantola, 2005):

$$
\mathbf{d}=G \mathbf{m},
$$

where $\mathbf{d}$ represents the data (SIWV), $G$ the model we will use, i.e the linear operator providing the length distribution of SIWV through the voxels and $\mathbf{m}$ represents our results, i.e. the water vapour density distribution in the voxels. A solution to that linear problem is given by a weighted least-square fit equation solution (Menke, 1989; Tarantola, 2005):

$$
\begin{aligned}
\mathbf{m}^{\text {est }}= & \mathbf{m}_{0}+\left(G^{t} \times \mathbf{W}_{\mathrm{GPS}} \times G+\alpha^{2} \times W_{\text {Model }}\right)^{-1} \\
& \times G^{t} \times \mathbf{W}_{\mathrm{GPS}} \times\left(d-G \times \mathbf{m}_{0}\right),
\end{aligned}
$$

where $\mathbf{m}_{0}$ is an a priori solution or first guess, $\mathbf{W}_{\mathrm{GPS}}$ corresponds to the inverse of the variance/covariance matrix 

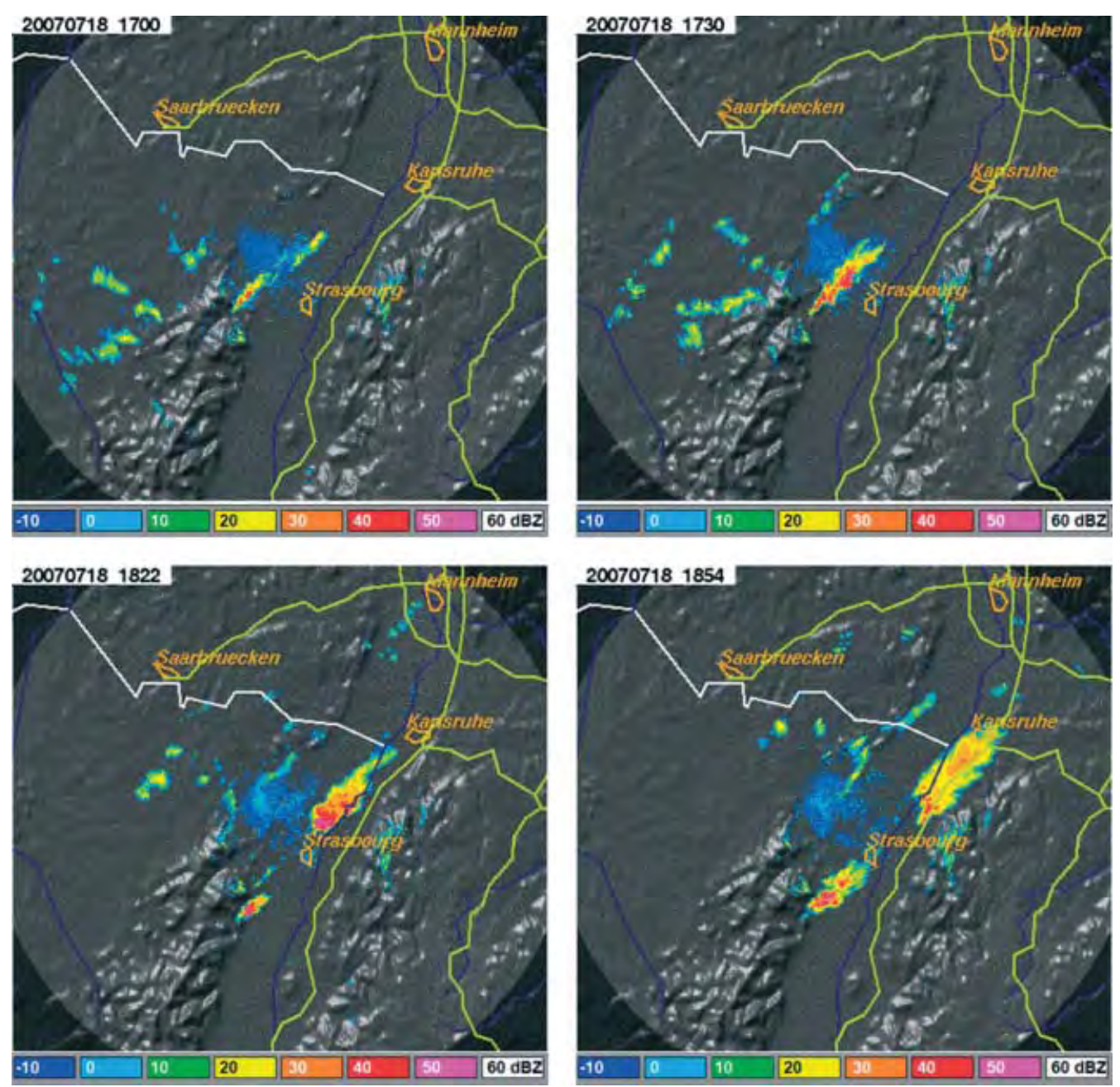

Figure 6. POLDIRAD reflectivity PPI observations on 18 July 2007 (IOP 9a) at 1700, 1730, 1822, and 1854 UTC. The colour scale indicates the reflectivity from -10 to $60 \mathrm{dBZ}$. This figure is available in colour online at wileyonlinelibrary.com/journal/qj

of the data errors: $\mathbf{W}_{\mathrm{GPS}}=\left(\mathbf{C}_{\mathrm{GPS}}\right)^{-1}, \mathbf{W}_{\text {Model }}$ corresponds to the matrix of the variability of the model around the $a$ priori values, $G$ is the model, and $\alpha$ is a weighting coefficient. In theory, by varying $\alpha$, one can vary the respective weight on the data or on the a priori estimation. If $\alpha$ is larger, more weight is given to the initialization in the solution and conversely, if $\alpha$ is smaller, more weight is given to the data. The influence of $\alpha$ is still the subject of ongoing sensitivity work, so we have chosen here a solution similar to a regular least-square fit by keeping $\alpha$ neutral, i.e. equal to 1 . Further details are provided by Reverdy (2008).

Another important step in the tomography inversion process is to initialize the inversion matrix, i.e. provide an 'a priori' solution. In our case, this is done with a standard atmosphere profile, i.e. an exponentially decreasing profile with altitude (McClatchey et al., 1972), adjusted to the voxel column IWV derived from the GPS measurements. First, the GPS-derived IWV field is interpolated throughout the analysis domain. Then, for each voxel column, the corresponding mean IWV and mean topography are computed. Finally, the standard profile contribution above the equivalent altitude is scaled to match the mean GPS-derived IWV and reported in the a priori solution for the corresponding voxel column. Thus, for the tomography that we have developed and implemented here, we rely uniquely on the GPS observables although making use of outside sources of information such as radiosondes (Champollion et al., 2009), and microwave profiling radiometers (MacDonald et al., 2002); even lidar measurements could easily be adapted and will be the object of future work. However, it has been our choice to restrict the GPS tomography by not using external water vapour profiles for two reasons: first, we wanted to avoid reducing the tomography to merely filling the time steps between successive profile interpolations (although we know we will lack vertical structure reconstruction when the spacing between GPS stations is too large), and second, the profiles' 'assimilation' strategies can have a significant influence on the resulting fields and we wanted to see how much could be extracted from GPS alone.

Once the water vapour field is initialized and the SIWV have been adequately distributed among the corresponding voxels, then the tomography resolution is merely a weighted least-square equation inversion problem (Reverdy, 2008), where the resulting matrix is the $3 \mathrm{D}$ distribution of water vapour density in the various voxels defined over the analysis domain.

In the case-studies presented here, the basic tomography was run with a $14 \times 14 \times 16$ voxel grid covering the COPS area from 47.5 to $49.5^{\circ} \mathrm{N}$ and from 6.25 to $9.25^{\circ} \mathrm{E}$, corresponding to a $16 \mathrm{~km}$ horizontal resolution and using all the GPS station data available for the domain (Figure 1). The height resolution was varied with altitude: $500 \mathrm{~m}$ height resolution up to $4 \mathrm{~km}$ of altitude, then $750 \mathrm{~m}$ 

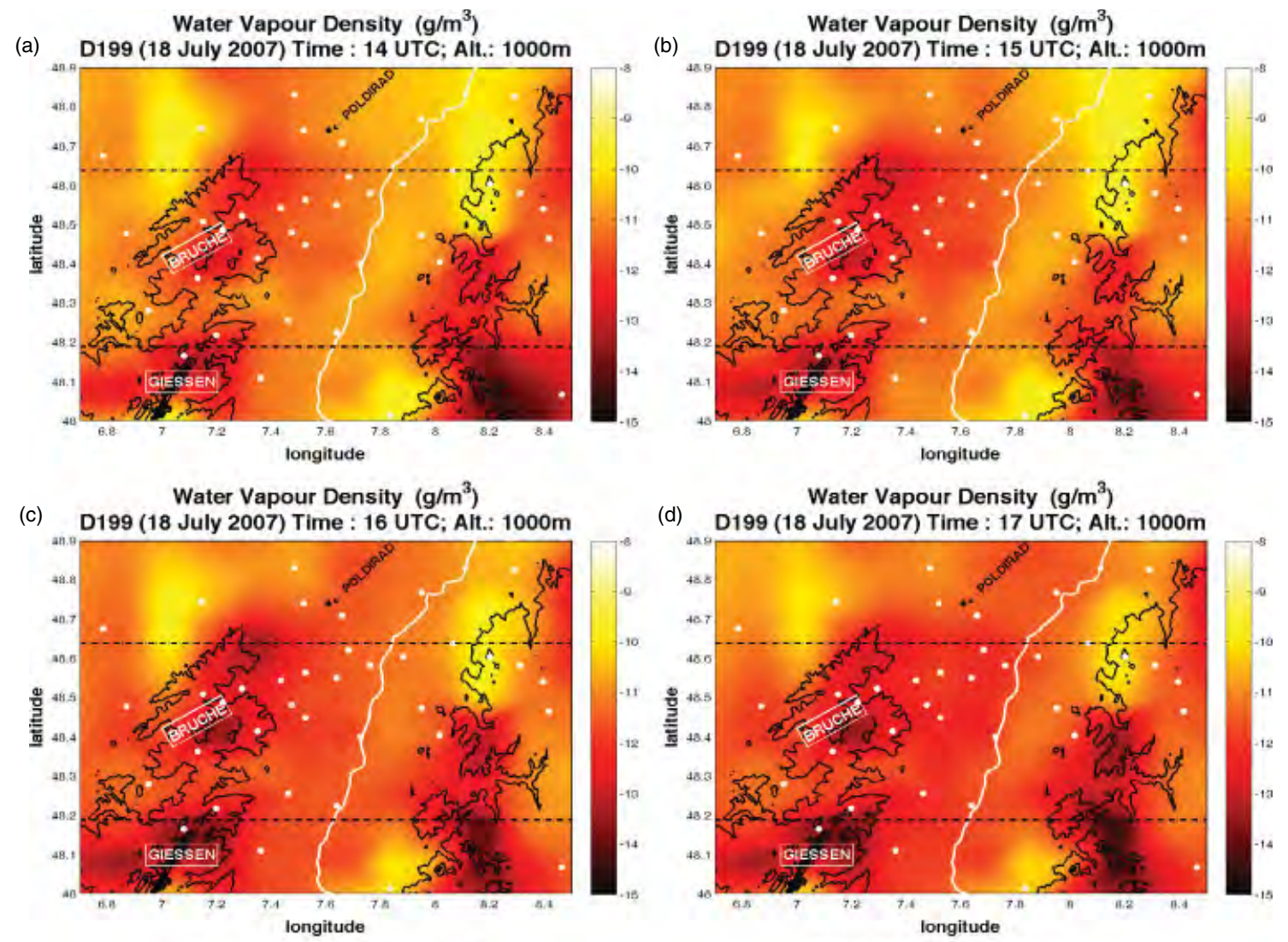

Water Vapour Density $\left(\mathrm{g} / \mathrm{m}^{3}\right)$
(e) D199 (18 July 2007) Time : 18 UTC; Alt.: $1000 \mathrm{~m}$
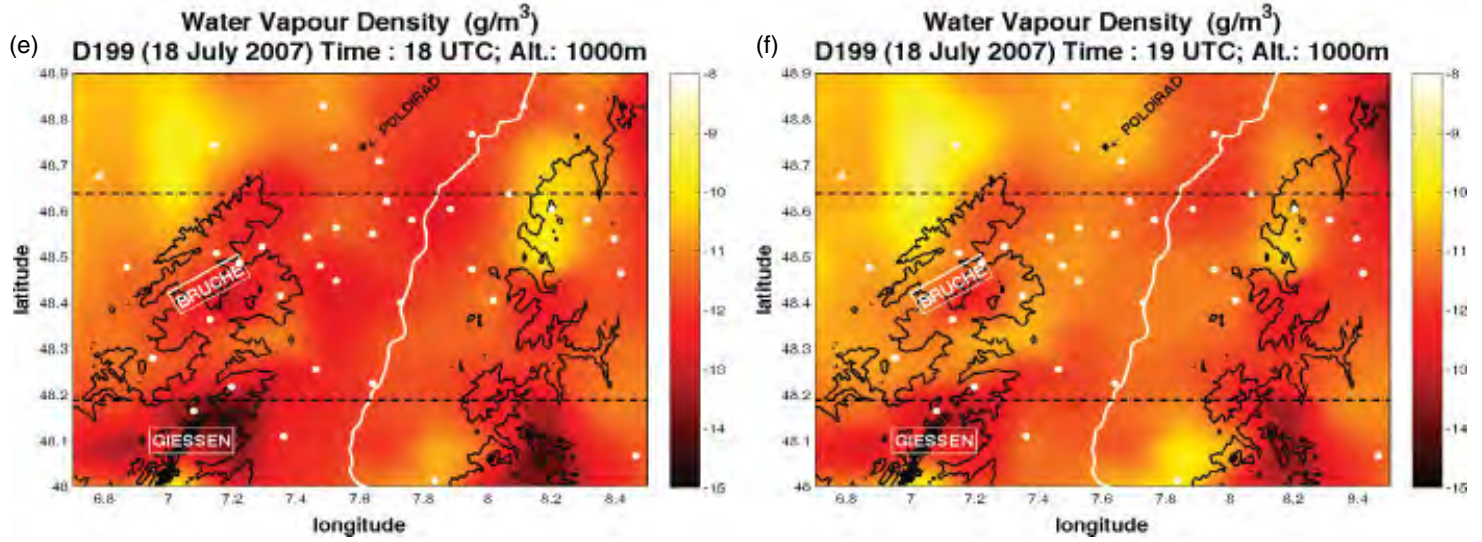

Figure 7. GPS tomography horizontal water vapour density fields for the $1000 \mathrm{~m}$ height layer on 18 July 2007 (IOP 9a) at (a) 1400, (b) 1500, (c) 1600, (d) 1700, (e) 1800, and (f) 1900 UTC. The water vapour density scale goes from 8 to $15 \mathrm{~g} \mathrm{~m}^{3}$ (from light to dark). The Bruche and Giessen valleys are indicated. The dash lines indicate the vertical cross-sections of Figure 8. This figure is available in colour online at wileyonlinelibrary.com/journal/qj

resolution up to $7 \mathrm{~km}$, and finally $1000 \mathrm{~m}$ resolution up to the maximum analysis height of $12 \mathrm{~km}$ where the water vapour is deemed negligible. For increased resolution, and to avoid artefacts due to lack of information brought about by excessive spacing between GPS stations, we have also run the tomography analysis on a subsection of the domain where the GPS station density was the largest $\left(48.0-48.9^{\circ} \mathrm{N}\right.$, $\left.6.7-8.5^{\circ} \mathrm{E}\right)$, with a $12 \times 12 \times 16$ voxel grid for a horizontal resolution of about $10 \mathrm{~km}(8.4 \mathrm{~km} \times 11.2 \mathrm{~km})$ and an unchanged vertical resolution of $500 \mathrm{~m}$ in the lower levels.

\section{Case-studies and discussion}

In this article, we have taken the approach to use exclusively GPS IWV fields and tomography water vapour retrieval in conjunction with local radar observations to consider the behaviour of the precipitation systems. Hence, the case-studies will necessarily be limited in their scope since numerous atmospheric parameters, such as those derived from radiosondes (Convective Available Potential Energy, CAPE; Convective Inhibition, CIN; Richardson number, etc.) or from Vienna Enhanced Resolution Analysis (VERA; Steinacker et al., 2006) (e.g. low-level dynamics), are not used or accounted for at this time.

Therefore, in these preliminary investigations, we aim at providing only a broad ensemble description of the processes involved rather than a detailed analysis of a single event. This descriptive approach is also dictated by some of the current physical limitations of tomography in this work. Indeed, with simple geometrical considerations based on the tomographic resolution (the size of the voxels) and the spacing between the network GPS stations (about double the voxel size on average), one can easily recognize that there will be a significant number of empty voxels, i.e. voxels with 
Water Vapor Density $\left(\mathrm{g} / \mathrm{m}^{3}\right)$

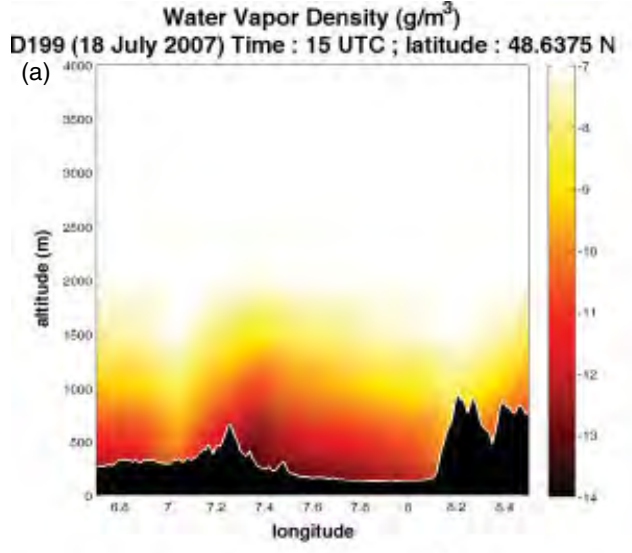

Water Vapor Density $\left(\mathrm{g} / \mathrm{m}^{3}\right)$
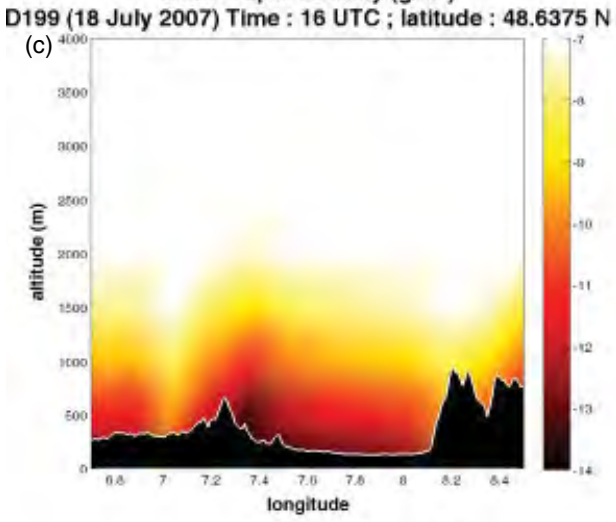

Water Vapor Density $\left(\mathrm{g} / \mathrm{m}^{3}\right)$

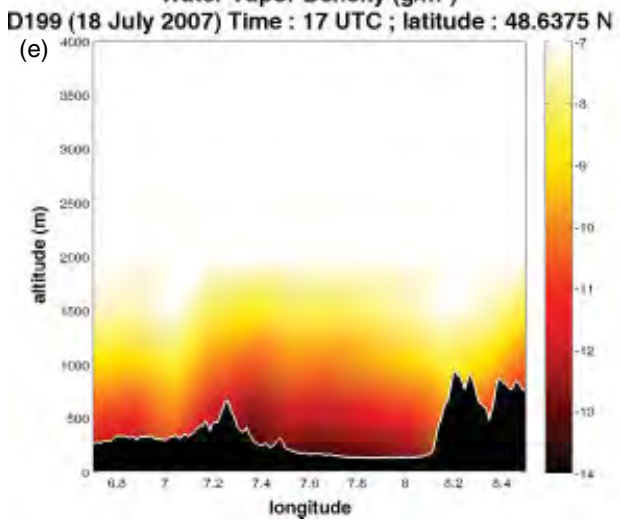

Water Vapor Density $\left(\mathrm{g} / \mathrm{m}^{3}\right)$

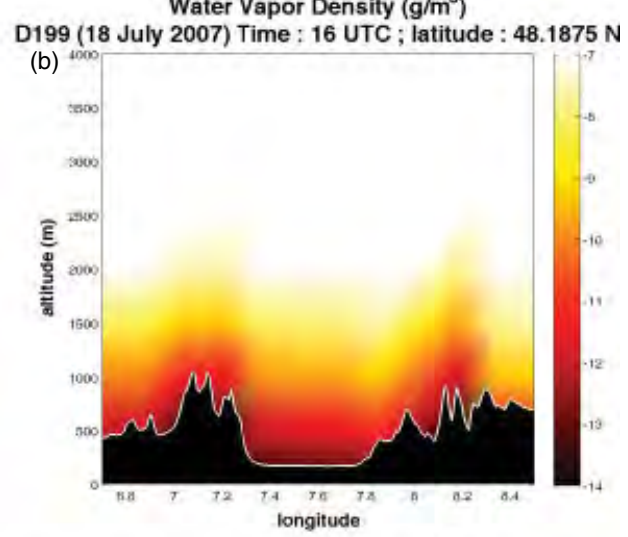

Water Vapor Density $\left(\mathrm{g} / \mathrm{m}^{3}\right)$

D199 (18 July 2007) Time : 17 UTC ; latitude : $48.1875 \mathrm{~N}$

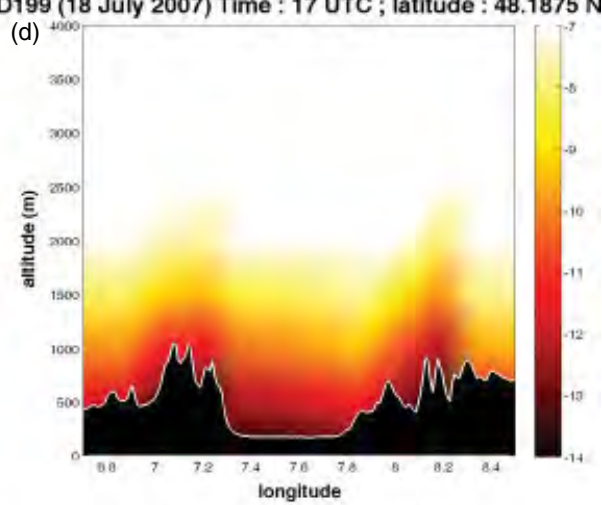

Water Vapor Density $\left(\mathrm{g} / \mathrm{m}^{3}\right)$

D199 (18 July 2007) Time : 18 UTC ; latitude : $48.1875 \mathrm{~N}$

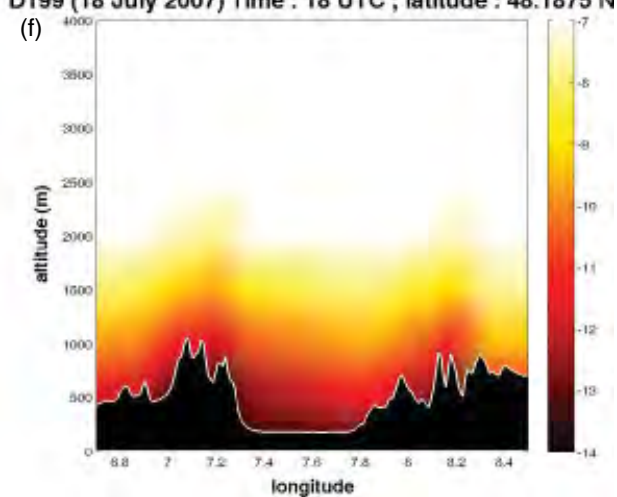

Figure 8. GPS tomography vertical water vapour density cross-sections on 18 July 2007 (IOP 9a) for latitude $48.64^{\circ} \mathrm{N}$ at (a) 1500 , (b) 1600 , and (c) 1700 UTC, and for $48.19^{\circ} \mathrm{N}$ at (d) 1600 , (e) 1700 , and (f) 1800 UTC. The water vapour density scale goes from 7 to $14 \mathrm{~g} \mathrm{~m}^{3}$ (from light to dark). This figure is available in colour online at wileyonlinelibrary.com/journal/qj

no rays crossing. That is especially true at the lower levels as rays from a given station will most probably stay within the boundaries of the lowest voxel above it, even with a $5^{\circ}$ elevation mask. On the lowest level, in the current geometry, about two thirds of the voxels are empty. Furthermore, at the levels just above, few voxels will be traversed by rays from different stations. These limitations could lead to a strongly indeterminate problem for the tomography inversion, and could question the benefits of tomography for simple IWV $2 \mathrm{D}$ maps or the impact on the a priori values. Furthermore, in those parts of the domain where there are very few GPS stations, such increased separation between stations can lead to artefacts due to the IWV interpolation in an area of contrasting topography, e.g. in the southeast corner of our larger domain. However, when spacing between stations becomes less than the voxel size, as is the case in the central part of the COPS domain (Figure 1), these restrictions are eased and the tomography inversion offers new insights into the water vapour field distribution and evolution. That is also why we have focussed our analysis on a smaller network with enhanced resolution whenever the meteorological situation of interest happened to take place within the region of denser GPS stations. Hence, the major obstacle in this work has come from the uneven spacing between GPS stations within the network. Statistical comparisons between a priori and tomography water vapour fields over the entire dataset have shown that, although there were little differences in those areas with few GPS stations, such as in the southeast and northwest parts of the domain, variations up to $10 \%$ of the retrieved water vapour density could be found in the central part of the domain where the campaign supersites were located, surrounded by the denser part of the GPS network. 

Water Vapour Density $\left(\mathrm{g} / \mathrm{m}^{3}\right)$

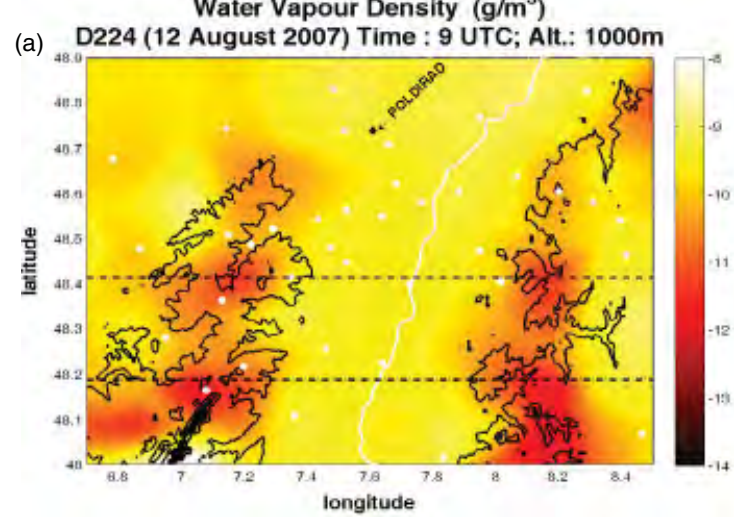

Water Vapour Density $\left(\mathrm{g} / \mathrm{m}^{3}\right)$

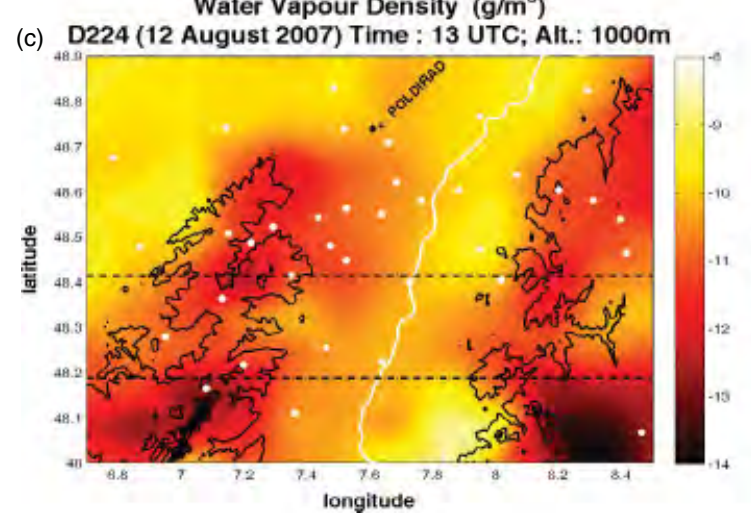

Water Vapour Density $\left(\mathrm{g} / \mathrm{m}^{3}\right)$

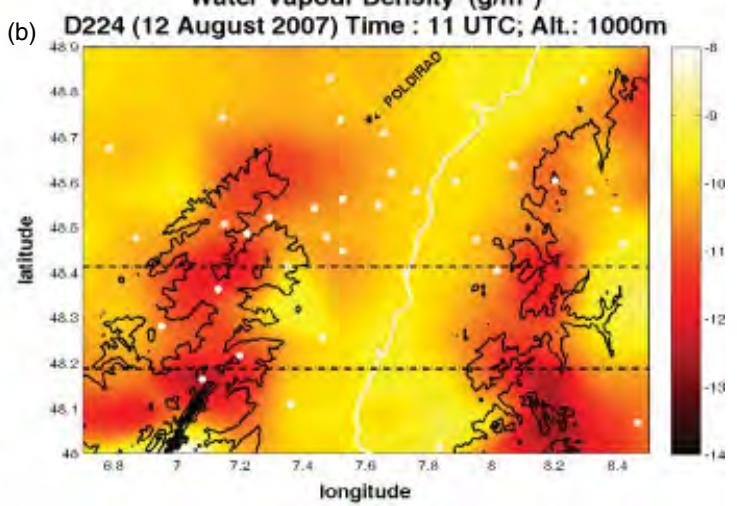

Water Vapour Density $\left(\mathrm{g} / \mathrm{m}^{3}\right)$

(d) D224 (12 August 2007) Time : 15 UTC; Alt.: $1000 \mathrm{~m}$

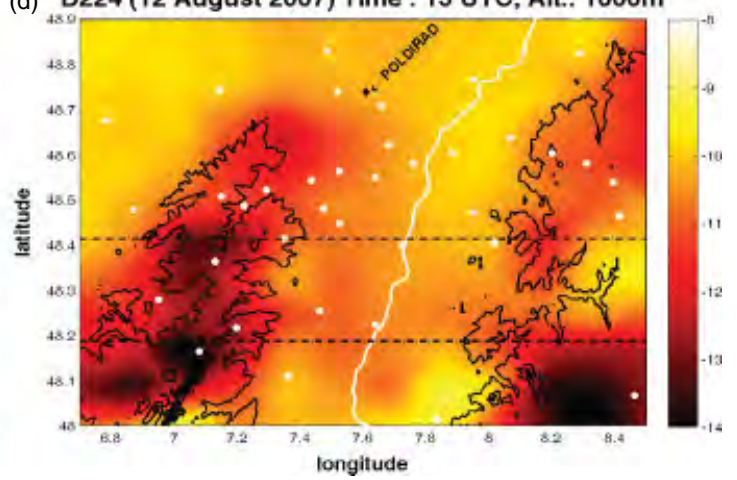

Figure 11. GPS tomography horizontal water vapour density fields for the $1000 \mathrm{~m}$ height layer at (a) 0900, (b) 1100 , (c) 1300 and (d) 1500 UTC on 12 August 2007 (IOP 15a). The water vapour density scale goes from 8 to $14 \mathrm{~g} \mathrm{~m}^{3}$ (from light to dark). The dashed lines indicate the vertical cross-sections in Figure 12. This figure is available in colour online at wileyonlinelibrary.com/journal/qj

Likewise, comparisons of tomography results with 2D IWV maps have shown that, although they were globally similar, some noticeable differences could be seen, especially in areas of marked contrast like fronts and other high-gradient situations, since the tomography is more able to retrieve the anisotropy of the water vapour distribution within the denser GPS part of the domain.

The basic question we want to address in this work is the possible link between particular water vapour patterns with the different types of convective initiation mechanisms and precipitation system characteristics encountered during COPS. To do so, we have based our case-study selection and partitioning on the general classification provided by Wulfmeyer et al. (2011) and Kottmeier et al. (2008):

(i) High pressure air-mass convection leading to locally initiated convection;

(ii) Forced widespread convection favoured by large-scale lifting and orographic effects; and

(iii) Forced convection embedded in frontal or convergence zones.

However, using radar observations, we can also use the differentiation established by Hagen et al. (2011) where convection initiation takes place either (a) on the mountain ridges or (b) on the lee side of the mountains.

\subsection{IOP 8 b, 15 July 2007}

This first case is certainly the most studied one among the many COPS IOPs recorded. Thus, we will not duplicate the detailed observation analyses and modelling presentations already made by Aoshima et al. (2008) and Kottmeier et al. (2008), as well as Wulfmeyer et al. (2011), Barthlott et al. (2011), Behrendt et al. (2011), and Richard et al. (2011). This list is certainly not exhaustive.

As shown on the radar reflectivity display (Figure 2), this event was characterized by a single isolated short-lived small but very intense convective cell that developed on the eastern ridges of the Black Forest and qualifies for a 'ridge' or 'high pressure air-mass convection' classification. On the POLDIRAD images, it is interesting to notice how the system initiates, grows, and develops through its entire life cycle with little advection, like a plume defined by a typical downstream $\mathrm{V}$ shape and attached to a localized hot spot.

In Figure 3, we show the IWV 2D field (left column) and the horizontal water vapour density for the $1000 \mathrm{~m}$ height layer (right column), both at hourly intervals from 1300 to 1500 UTC. Looking at these water vapour field distributions, we have to keep in mind that these might not be the best GPS analysis conditions for tomography since this area does not lie within the denser part of the GPS network, even though there is one GPS station not far from the active cell area depicted by the black circle. Also, given that the resolution of the water vapour tomography is of the order of $16 \mathrm{~km}$, there is little hope of identifying the hot spot where convection was activated, but we can look at the larger-scale evolution. In the early afternoon, a build-up of humidity over the southern Black Forest ridges is clearly visible, possibly provided by the southwesterly flow (Wulfmeyer et al., 2011; Richard et al., 2011). However, between 1300 and 1500 UTC, the water vapour field appears to decrease in the area where the convective cell (around $48.2^{\circ} \mathrm{N}, 8.3^{\circ} \mathrm{E}$ ) later developed. Hence, water vapour depletion started more than 

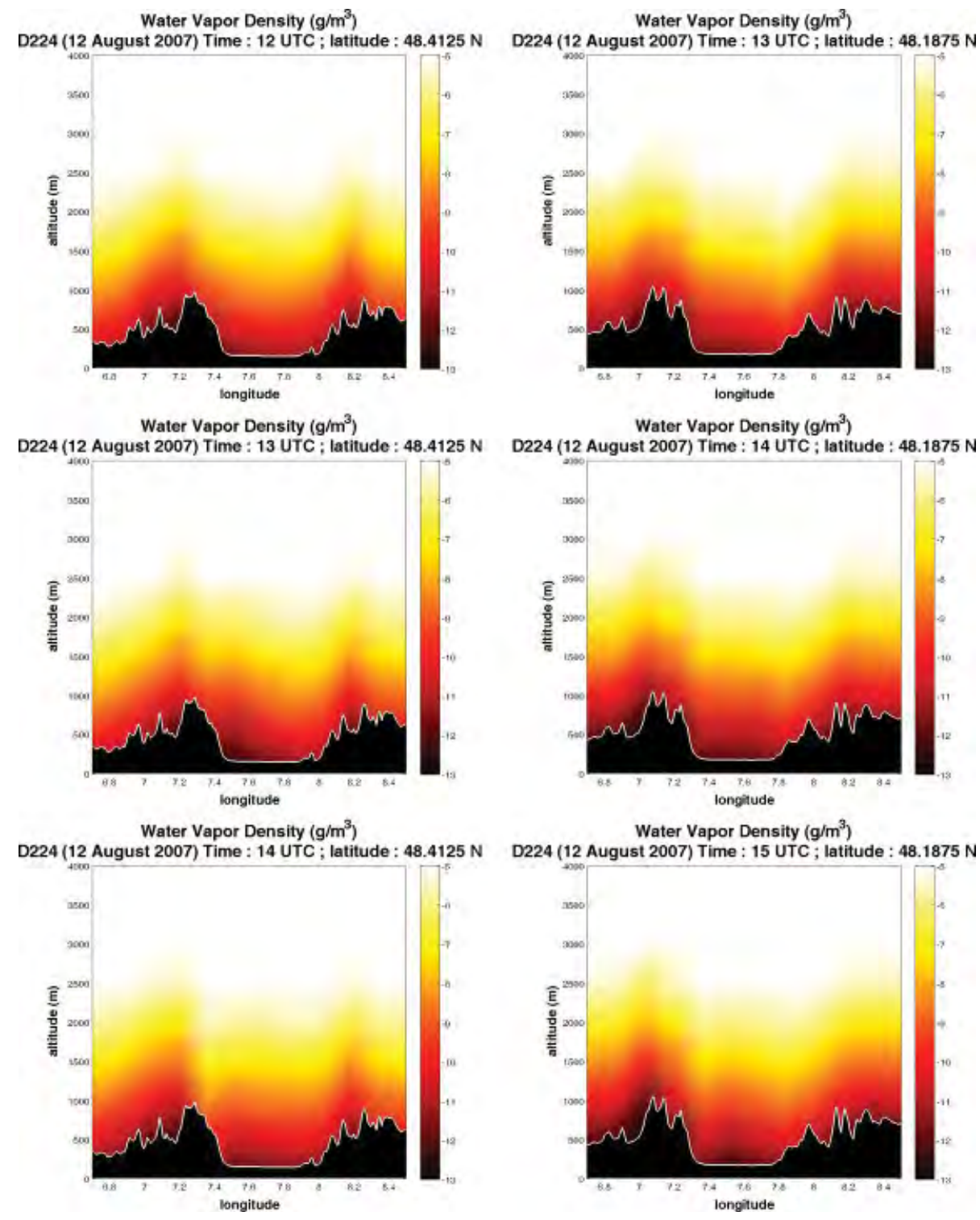

Water Vapor Density $\left(\mathrm{g} / \mathrm{m}^{3}\right)$

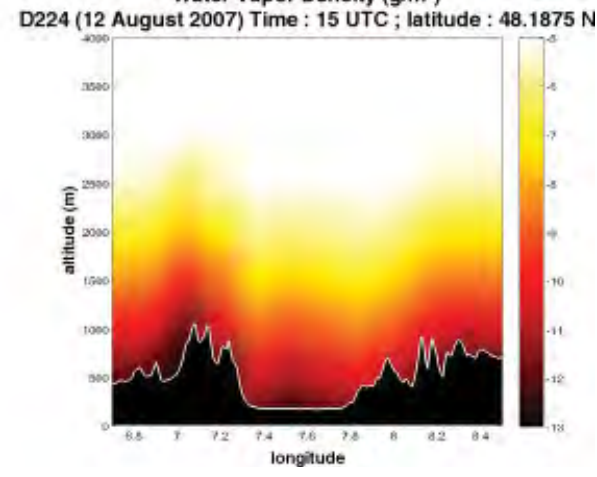

Figure 12. GPS tomography vertical water vapour density cross-sections at constant latitude $48.41^{\circ} \mathrm{N}$ (left column) and $48.19^{\circ} \mathrm{N}$ (right column) from 12:00 to 14:00 and 13:00 to 15:00 UTC, respectively, on August 122007 (IOP 15a). The water vapour density scale goes from 5 to $13 \mathrm{~g} \mathrm{~m}^{3}$ (from light to dark). This figure is available in colour online at wileyonlinelibrary.com/journal/qj

one hour before the onset of the precipitation. Comparing the tomography result to the IWV field, it is interesting to note that tomography provides a better visual description of the local variation of water vapour, although one must argue that IWV is affected by the topography and that its variation relative to a daily mean or some other reference value would also exhibit similar build-up and decrease. This fact seems to indicate that, perhaps due to local forcing triggered by a singularity in the orography or in the ground cover or vegetation, there is a transfer from water vapour to liquid water. Indeed, GPS measures water vapour content of the atmosphere but is not sensitive to liquid (or solid) water (Solheim et al., 1999). This transfer implies the creation and/or enhancement of clouds by generation of hydrometeors first through condensation, but perhaps also through washing of the lower atmosphere once the rain has started to fall. Such water vapour depletion to support cloud formation before heavy precipitation onset has already been considered by Van Baelen and Penide (2009), but the COPS experiment offers the first opportunity to actually observe both the $3 \mathrm{D}$ water vapour field and the precipitation system development simultaneously. Further evidence is provided by the individual time series of IWV corresponding to four GPS stations surrounding the location of convective precipitation activity (Figure 4). Indeed, one can see the northeastward progression of a peak of humidity within the couple of hours before noon brought by the synoptic flow (which also cleared away a pool of humidity that stagnated in the plain to the southeast of the Black Forest in the morning). Then, by 1200 UTC, water vapour starts decreasing significantly, indicating the possible condensation process, while water vapour reaches its minimum at the time the precipitation occurs.

\subsection{IOP $9 c, 20$ July 2007}

This case is an example of forced convection embedded in a frontal zone characterized by high water vapour densities moving ahead of the front (Corsmeier et al., 2011). In the scope of this paper, it serves as a support to illustrate two interesting interactions between the water vapour field and precipitation systems. However, given that the GPS station 

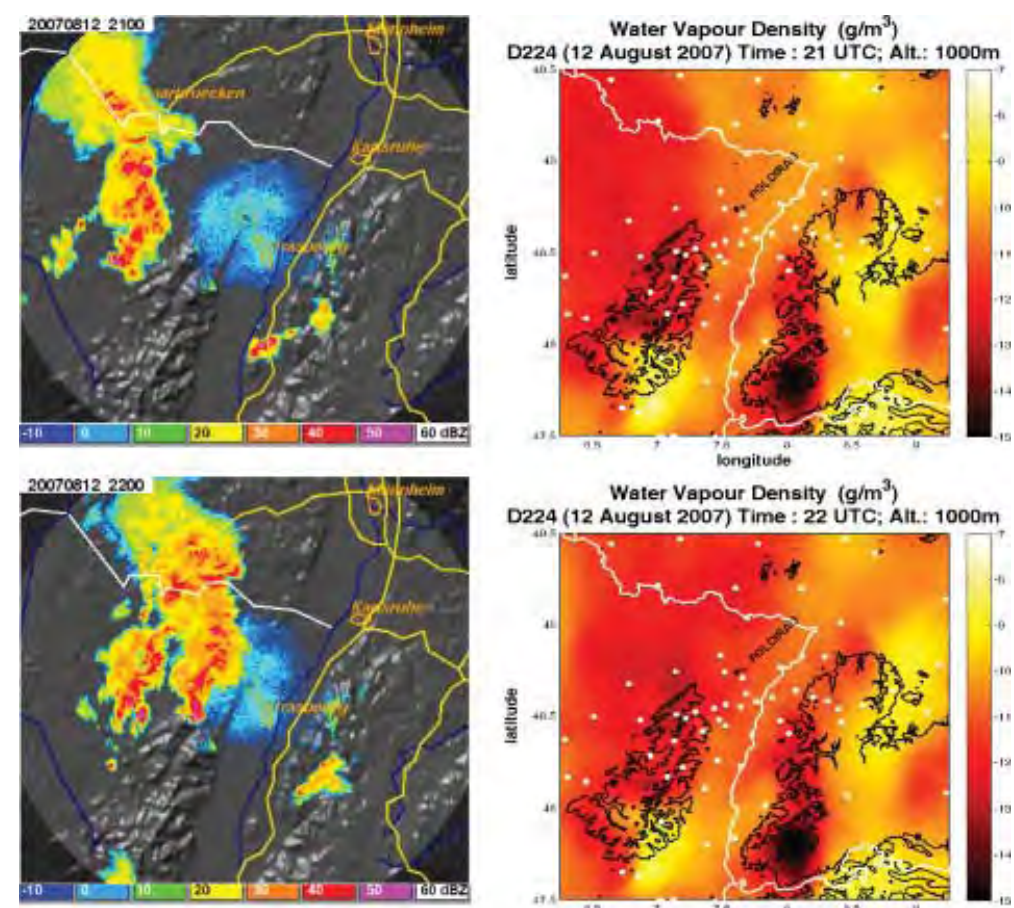

Water Vapour Density $\left(\mathrm{g} / \mathrm{m}^{3}\right)$
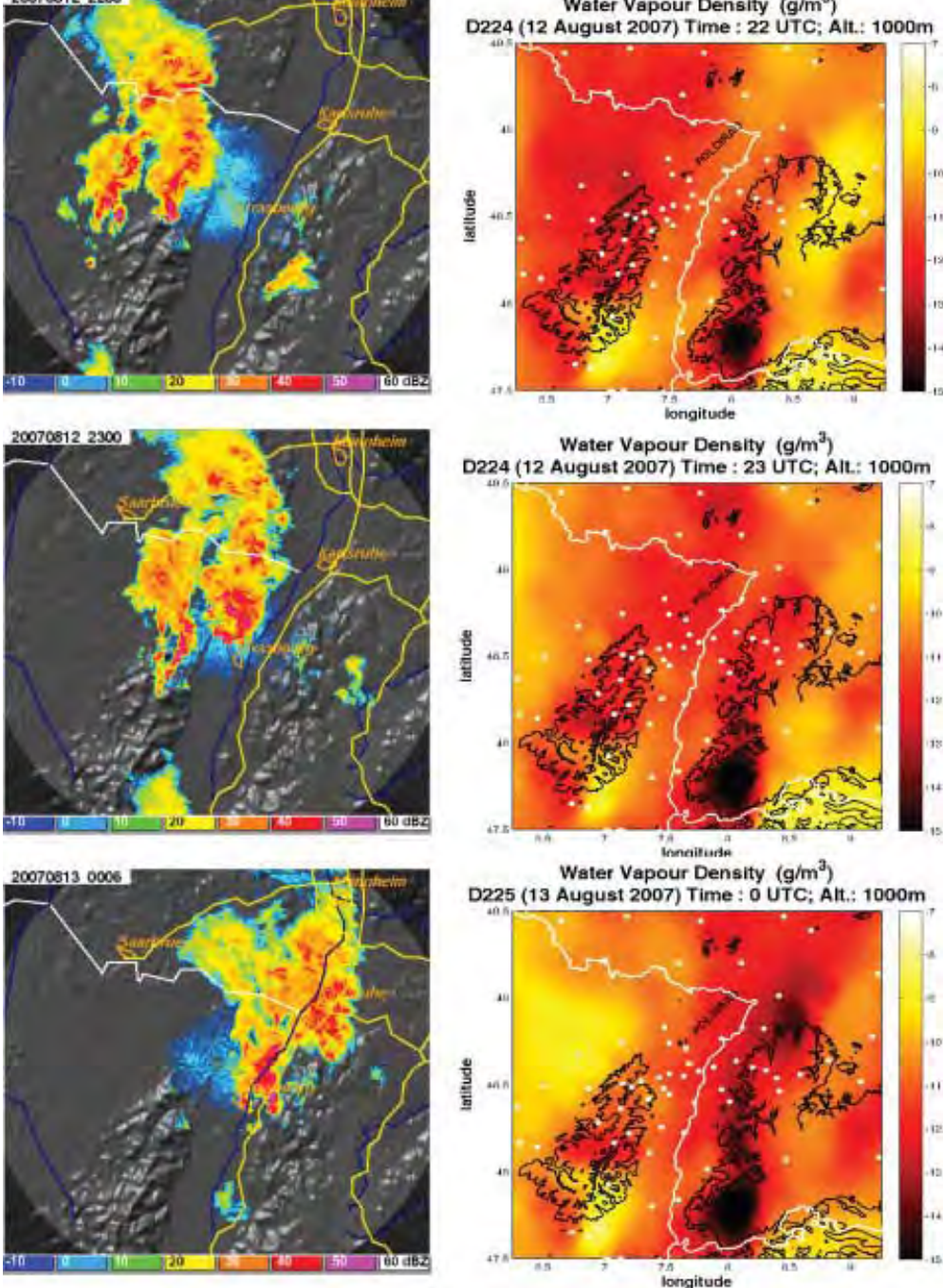

Figure 13. POLDIRAD reflectivity PPI observations on 12 August 2007 at 21:00, 22:00, 23:00, and August 132007 at 00:00 UTC (IOP 15), respectively (left column) and GPS tomography horizontal water vapour density fields at the $1000 \mathrm{~m}$ height layer for the same times (right column). The radar reflectivity scale goes from -10 to $60 \mathrm{DBz}$. The water vapour density scale goes from 7 to $15 \mathrm{~g} \mathrm{~m}^{3}$ (from light to dark). This figure is available in colour online at wileyonlinelibrary.com/journal/qj

density is not homogeneous across the event analyzed, we will consider both IWV fields and tomography results.

First, in Figure 5, when comparing the POLDIRAD 1000 UTC reflectivity plot with the integrated water vapour distribution retrieved at the same time, it is noticeable that an excellent correlation exists between the line of active cells (the high reflectivity centres in red) within the front (the area of moderate reflectivity values in green) and the areas of water vapour depletion. Those areas are highlighted by a white arc on the corresponding figures and exhibit a deficit of more than $6 \mathrm{~mm}$ (up to 15\%) of integrated water vapour. Such differences are significantly larger than the recognized accuracy of GPS water vapour retrievals. Hence, this point further demonstrates the possible transfer from water vapour into liquid water (hydrometeors) in the areas of active convection, while further depletion might be produced by aggregation of the atmospheric water vapour by the hydrometeors as they fall to the ground.

Second, considering now the water vapour distribution at 1000 UTC at the $1000 \mathrm{~m}$ level and the POLDIRAD 1030 UTC reflectivity map, it appears that the frontal line development is favoured in those places where there exist 

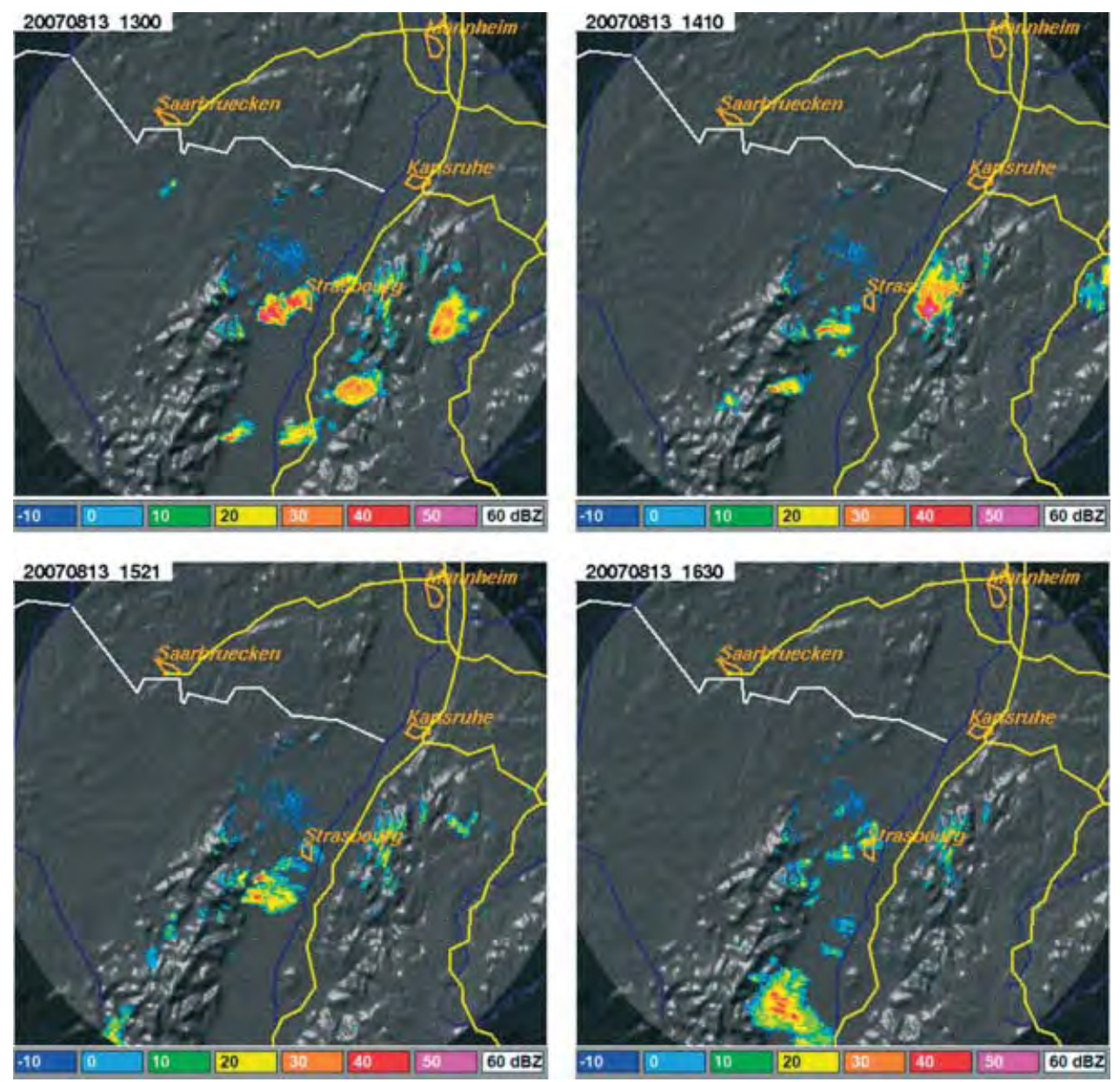

Figure 14. POLDIRAD reflectivity PPI observations of isolated cells on 13 August 2007 (IOP 15b) at 1300, 1410, 1521, and 1630 UTC. The colour scale indicates the reflectivity from -10 to $60 \mathrm{DBz}$. This figure is available in colour online at wileyonlinelibrary.com/journal/qj

enhanced water vapour 'reservoirs'. In this instance, this is particularly visible around $48.8^{\circ} \mathrm{N}, 8.5^{\circ} \mathrm{E}$, while tomography also reveals the area on the lee of the Vosges at the southern end of the precipitation system. This seems to indicate that pre-existing water vapour conditions play a dominant role in frontal development. Nonetheless, this figure also illustrates a current limitation with tomography in those regions with few GPS stations; artefacts can appear and mask the actual water vapour signature, as is the case here over the southern Black Forest mountains.

\subsection{IOP $9 a, 18$ July 2007}

We selected this case because of the very localized convection spots that could be observed with POLDIRAD. Referring to the proposed classifications, this is also a case of convective activity favoured by large-scale lifting due to strong flow aloft and the creation of isolated cells. Obviously, this is also a case of lee-side convection as all the cells observed develop on the eastern side of the Vosges. Figure 6 presents some examples of the convective and precipitation activity observed with POLDIRAD. The first one (1700 and 1730 UTC) takes place at the exit of the Bruche valley. There, the radar reveals that the convection is triggered by a small hill within the valley exit range. Likewise, the 1822-1854 UTC cell to the south of the Vosges supersite is also triggered by a hill at the foot of the mountain range close to the exit of the Giessen valley.
In these instances, and in contrast with the July 15 case, the water vapour density does not build up on top of the mountain but appears to cross the ridges and flow down the lee side of the Vosges into its deepest valleys. This is well indicated in Figure 7 where the water density fields at the $1000 \mathrm{~m}$ altitude level from 1400 to 1900 UTC illustrate the water vapour outflow that takes place from the Vosges mountain valleys before continuing across the Rhine Valley. At first (1500-1600 UTC), high values of water vapour are is located at the exit of the Bruche valley; these then cross the southern lee side of the Vosges range, particularly around the Giessen valley (1700-1800 UTC). On Figure 8, paying close attention to the $7.4^{\circ} \mathrm{E}$ zone on the cross-sections provided at $48.64^{\circ} \mathrm{N}$ (Bruche valley) and $48.19^{\circ} \mathrm{N}$ (Giessen valley), one can see the marked water vapour density reinforcement at the lowest level, while little accumulation occurs on the west side of the mountains ranges or on their ridges as the water vapour crosses the Vosges and spreads across the Rhine valley.

Hence, one can consider that the strong flow aloft is responsible for the water vapour crossing over the mountain ridges and not accumulating over the mountain tops. Accordingly, water vapour fields retrieved from the GPS tomography indicate that it is the moist air descending from the crests into the valleys that triggers the convection initiation when the flow meets a hill at the exit of the valley, thus creating abrupt lifting of the low-level air mass. 
Water Vapour Density $\left(\mathrm{g} / \mathrm{m}^{3}\right)$

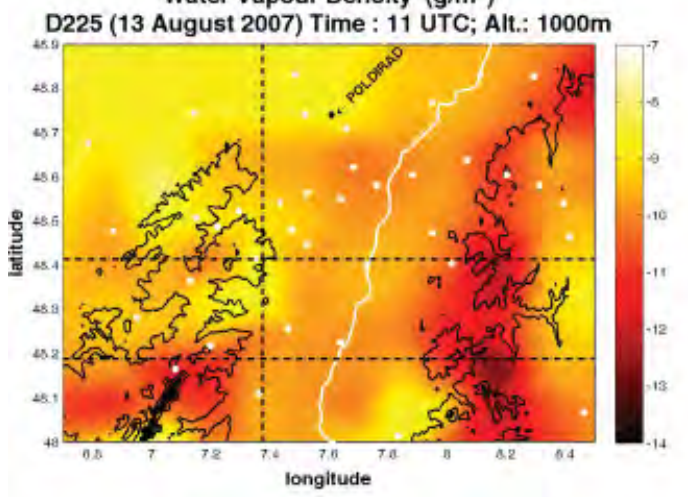

Water Vapour Density $\left(\mathrm{g} / \mathrm{m}^{3}\right)$ D225 (13 August 2007) Time: 13 UTC; Alt: $1000 \mathrm{~m}$

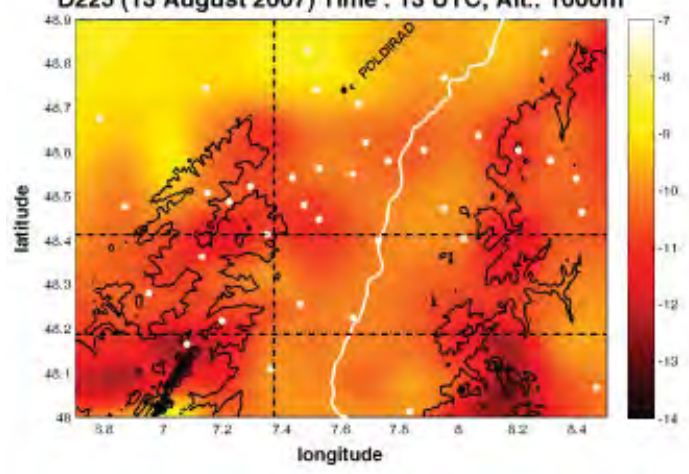

Water Vapour Density $\left(\mathrm{g} / \mathrm{m}^{3}\right)$

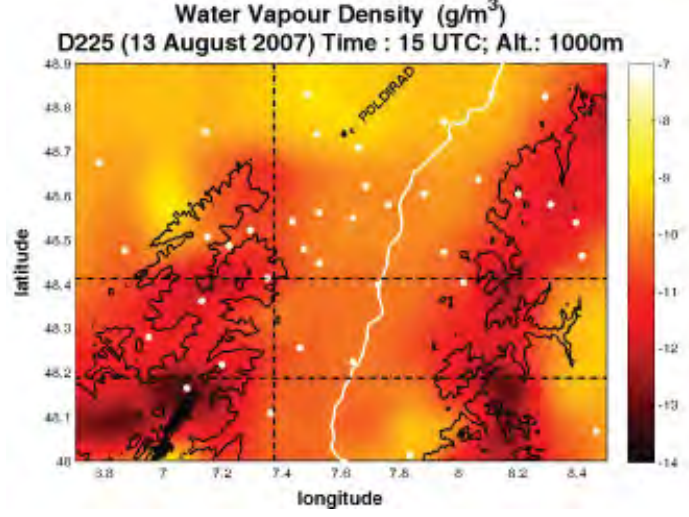

Water Vapour Density $\left(\mathrm{g} / \mathrm{m}^{3}\right)$

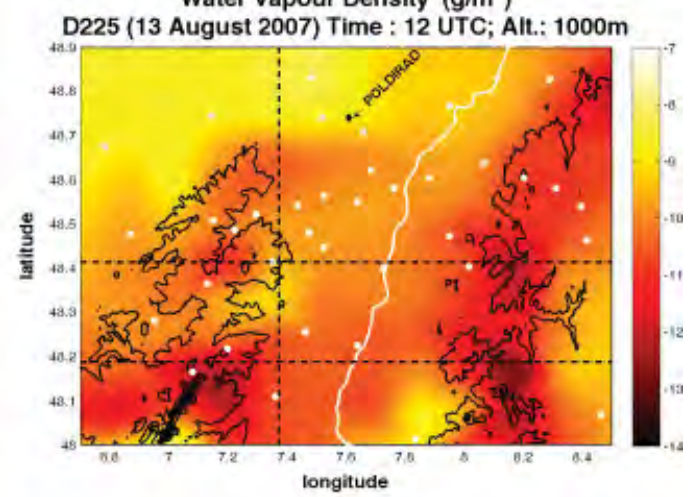

Water Vapour Density $\left(\mathrm{g} / \mathrm{m}^{3}\right)$ D225 (13 August 2007) Time : 14 UTC; Alt: $1000 \mathrm{~m}$

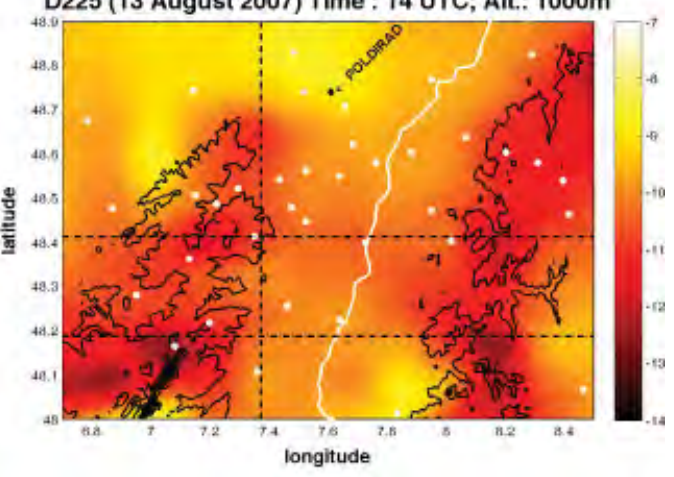

Water Vapour Density $\left(\mathrm{g} / \mathrm{m}^{3}\right)$

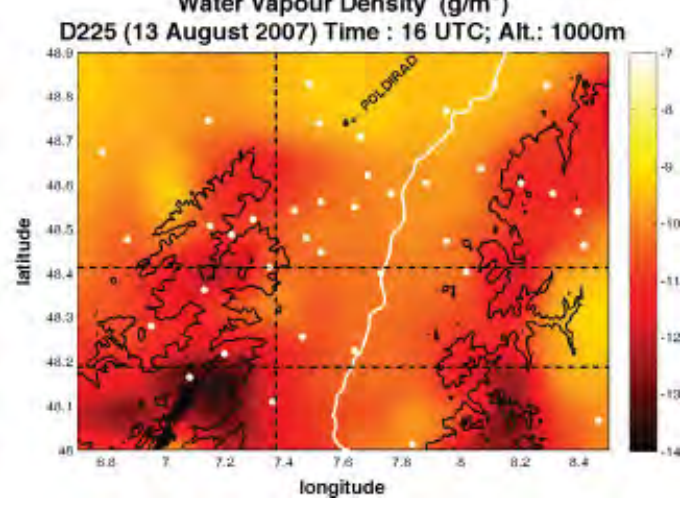

Figure 15. GPS tomography horizontal water vapour density for the $1000 \mathrm{~m}$ height layer from 11:00 to 16:00 UTC on August 13 2007 (IOP 15b). The water vapour density scale goes from 7 to $14 \mathrm{~g} \mathrm{~m}^{3}$ (from light to dark). The dashed lines indicate the vertical cross-sections of Figures 16 and 17 . This figure is available in colour online at wileyonlinelibrary.com/journal/qj

Furthermore, taking advantage of the UHF boundarylayer wind profiler operation at the nearby Vosges supersite (Figure 9), one can see that during the corresponding time between 1600 and 1800 UTC, the wind field is characterized by westerly flow aloft (above $1.5 \mathrm{~km}$ ) but easterly, upslope winds in the lowest $500 \mathrm{~m}$, causing low-level convergence along the Vosges lee side. Thus, we can speculate that the outgoing flow from the valleys is meeting this upslope wind coming from the Rhine, further enhancing the lifting effect of hills near the exit of those valleys and enabling convective initiation.

\subsection{IOP 15, 12-13 August 2007}

IOP 15 is of particular interest since three separate casestudies occur in the course of two days. First, there is 'ridge' convection on 12 August afternoon, mainly on the Vosges, followed by a frontal passage in the Rhine valley in the early hours of the night, before 'lee-side' convection takes place on 13 August afternoon. Extensive work on the convective activity observed with radars, and on the role of the wind field in the convection-forcing mechanisms, has already been developed in Hagen et al. (2011) and, to a lesser extent in Bennett et al. (2011) and Planche et al. (2010), so here we will keep our focus on the interactions between water vapour fields and convective and precipitating systems.

Figure 10 shows a series of radar observations of the 'ridge' event on 12 August. POLDIRAD reveals the largescale extent of the isolated cell development over the Vosges crests. Also, cell track origins (Hagen et al., 2011) for the entire episode show that the convection initiation process is confined to the ridges, and their relatively small extent, with most cells decaying as they reach the Rhine Valley, indicates that the advection is weak and that there must be little moisture available over the plains to fuel the convection process. The associated water vapour field 

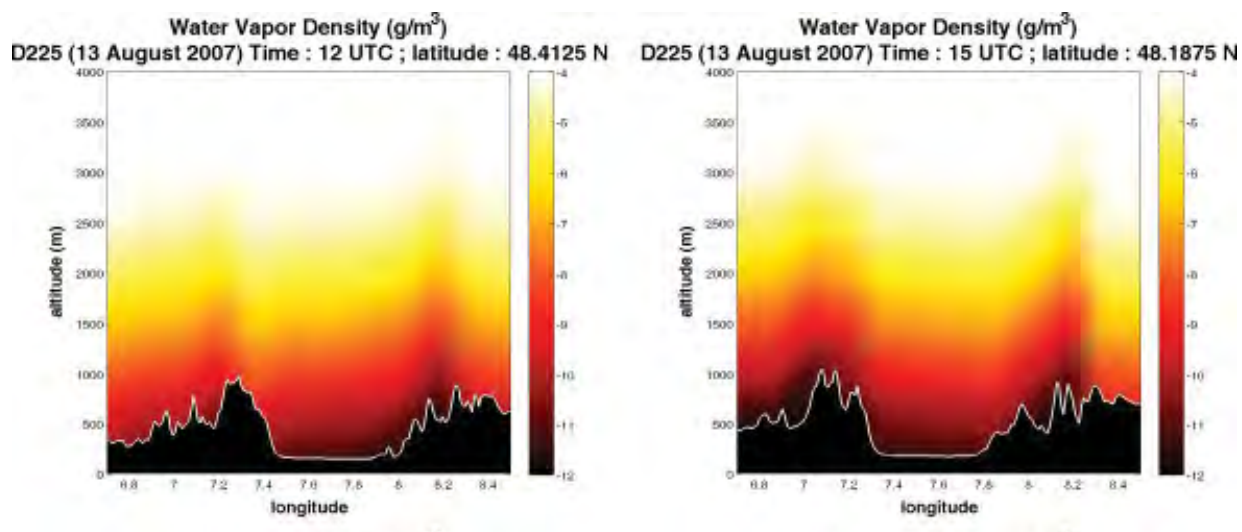

Water Vapor Density $\left(\mathrm{g} / \mathrm{m}^{3}\right)$ D225 (13 August 2007) Time: 13 UTC ; latitude : $48.4125 \mathrm{~N}$

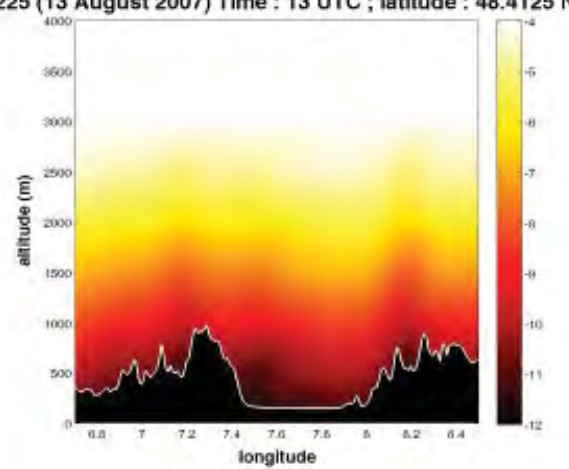

Water Vapor Density $\left(\mathrm{g} / \mathrm{m}^{3}\right)$ D225 (13 August 2007) Time : 14 UTC ; latitude : $48.4125 \mathrm{~N}$
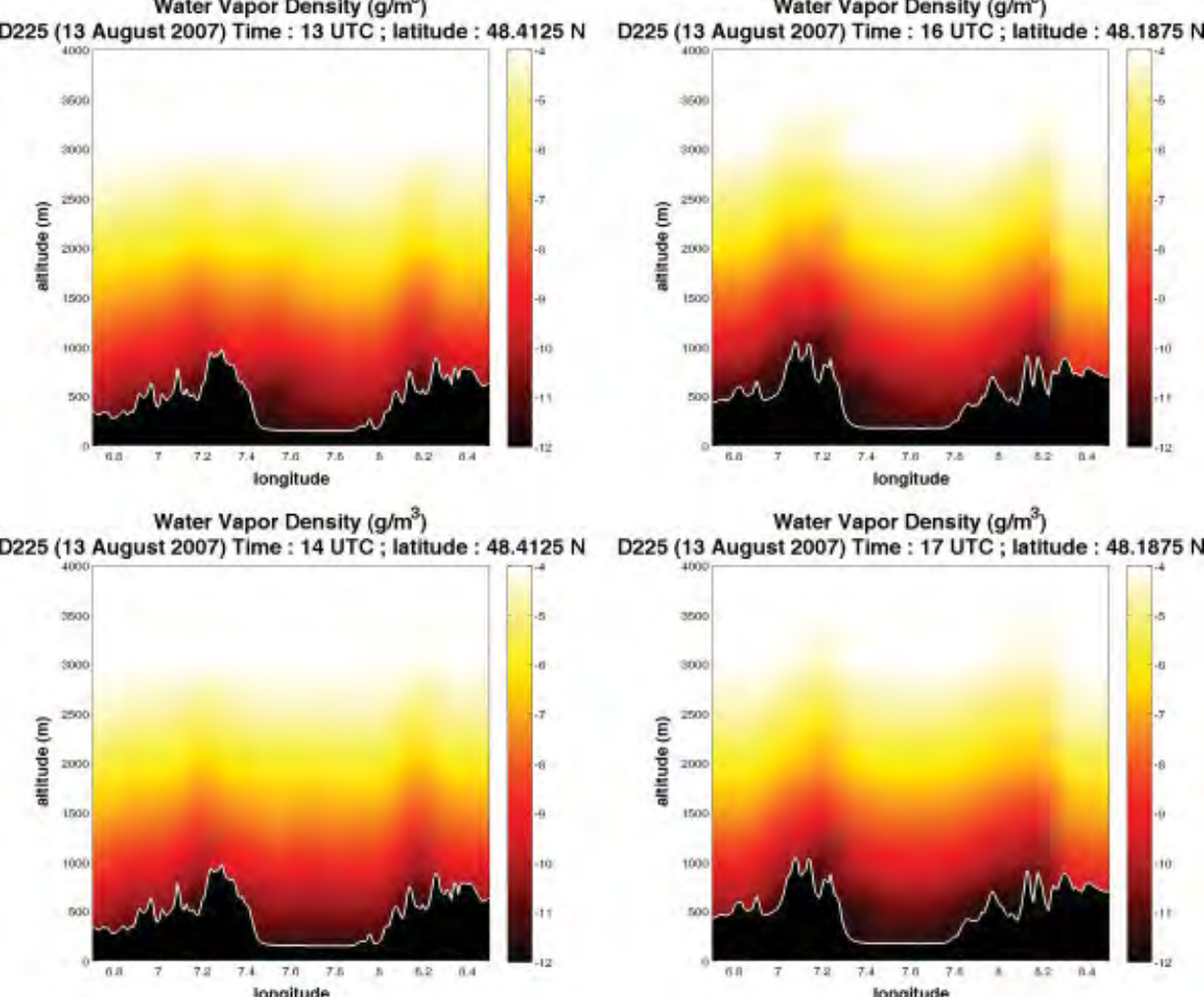

Water Vapor Density $\left(\mathrm{g} / \mathrm{m}^{3}\right)$

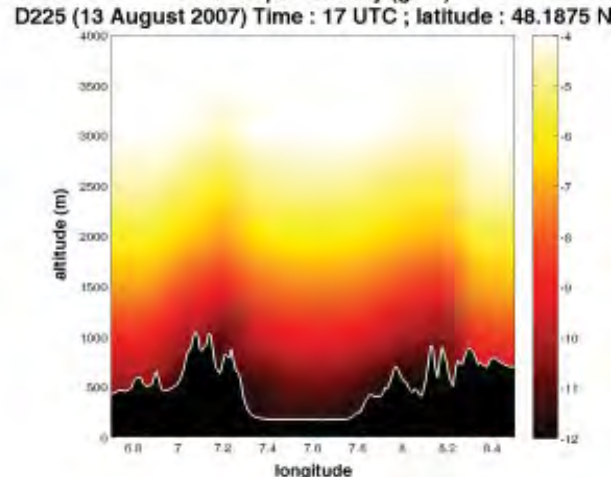

Figure 16. GPS tomography vertical water vapour density cross-sections at constant latitude $48.41^{\circ} \mathrm{N}$ (left column) and $48.19^{\circ} \mathrm{N}$ (right column) from 12:00 to 14:00 and 15:00 to 17:00 UTC, respectively, on August 132007 (IOP 15b). The water vapour density scale goes from 4 to $12 \mathrm{~g} \mathrm{~m}^{3}$ (from light to dark). This figure is available in colour online at wileyonlinelibrary.com/journal/qj

distribution estimated with GPS tomography (Figures 11 and 12) further confirms that there is accumulation of water vapour from mid-morning up to early afternoon over the Vosges Mountains to support the localized convection. In particular, the cross-sections at $48.41^{\circ} \mathrm{N}$ and $48.19^{\circ} \mathrm{N}$, passing through very active areas of the Vosges convective zones, clearly show that the water vapour does not cross the main Vosges ridge but accumulates over the crests.

During the following night, there is a frontal passage with sustained precipitation that is well documented by POLDIRAD as illustrated in Figure 13. This case can be considered as forced convection embedded within a (cold) frontal zone. In this instance, the corresponding water vapour field behaves rather differently from those of the 15 July and 20 July cases. Indeed, it appears here that the rain activity is already well established when the system enters the COPS domain with a strong and active front brought by large-scale synoptic forcing. Hence, we have no indication regarding the possible transfer of water vapour into liquid water to support the creation and development of clouds and the onset of precipitation associated with water vapour depletion. Instead, we notice that at 2100 UTC the precipitation system contour is well correlated with a zone of high water vapour density denoting humidity saturation associated with the frontal system. Later, however, high water vapour density appears to extend ahead of the frontal system, depicting possible storm outflow activities such as those reported by Collier et al. (2008). Finally, at 0000 UTC on 13 August there is evidence of interaction between the orography and the development of the frontal system as water vapour propagation is stopped by and accumulates against the foothills of the Black Forest before rounding its northern tip.

Later in the afternoon of 13 August, well after the frontal passage, a new episode of isolated convection took place but this time it happened in the lee of the Vosges. This is shown by the POLDIRAD observations of Figure 14, where individual cell formations can be monitored. The reported locations of 

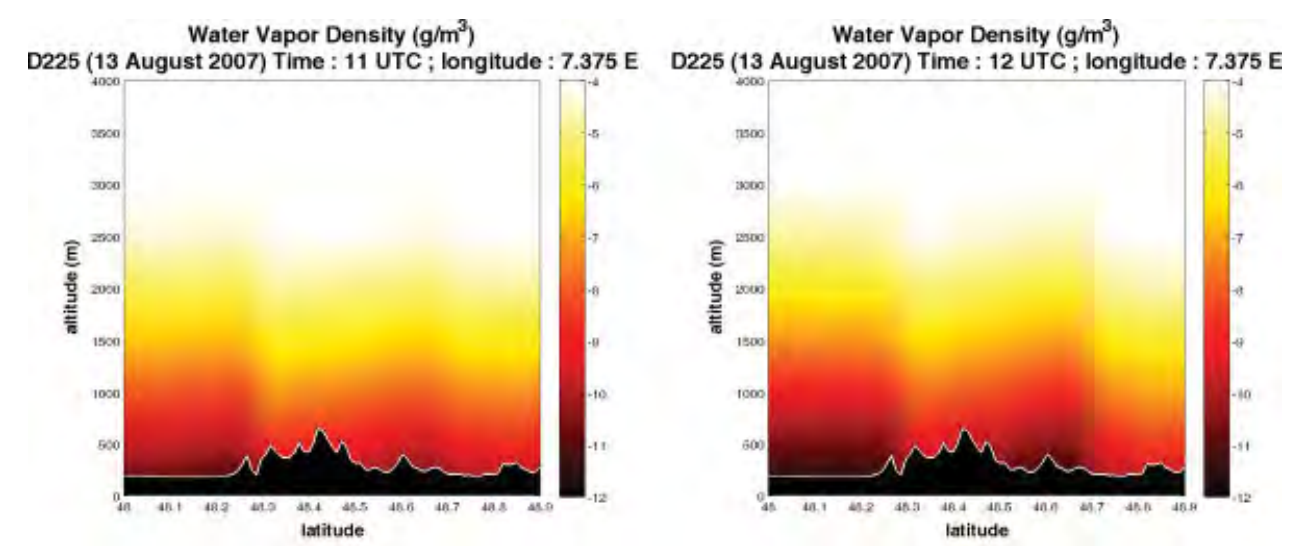

Water Vapor Density $\left(\mathrm{g} / \mathrm{m}^{3}\right)$ D225 (13 August 2007) Time : 13 UTC; longitude : $7.375 \mathrm{E}$

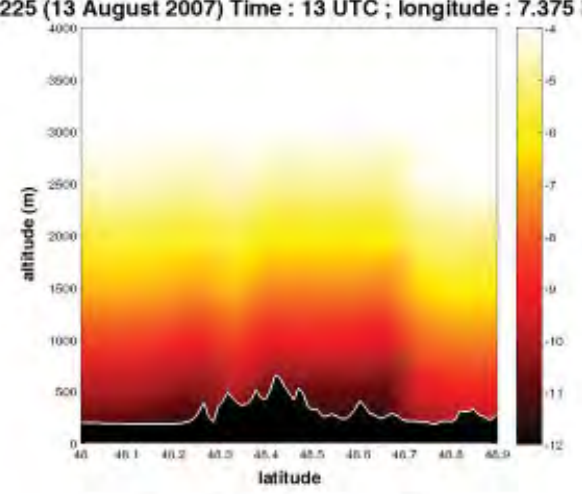

Water Vapor Density $\left(\mathrm{g} / \mathrm{m}^{3}\right)$
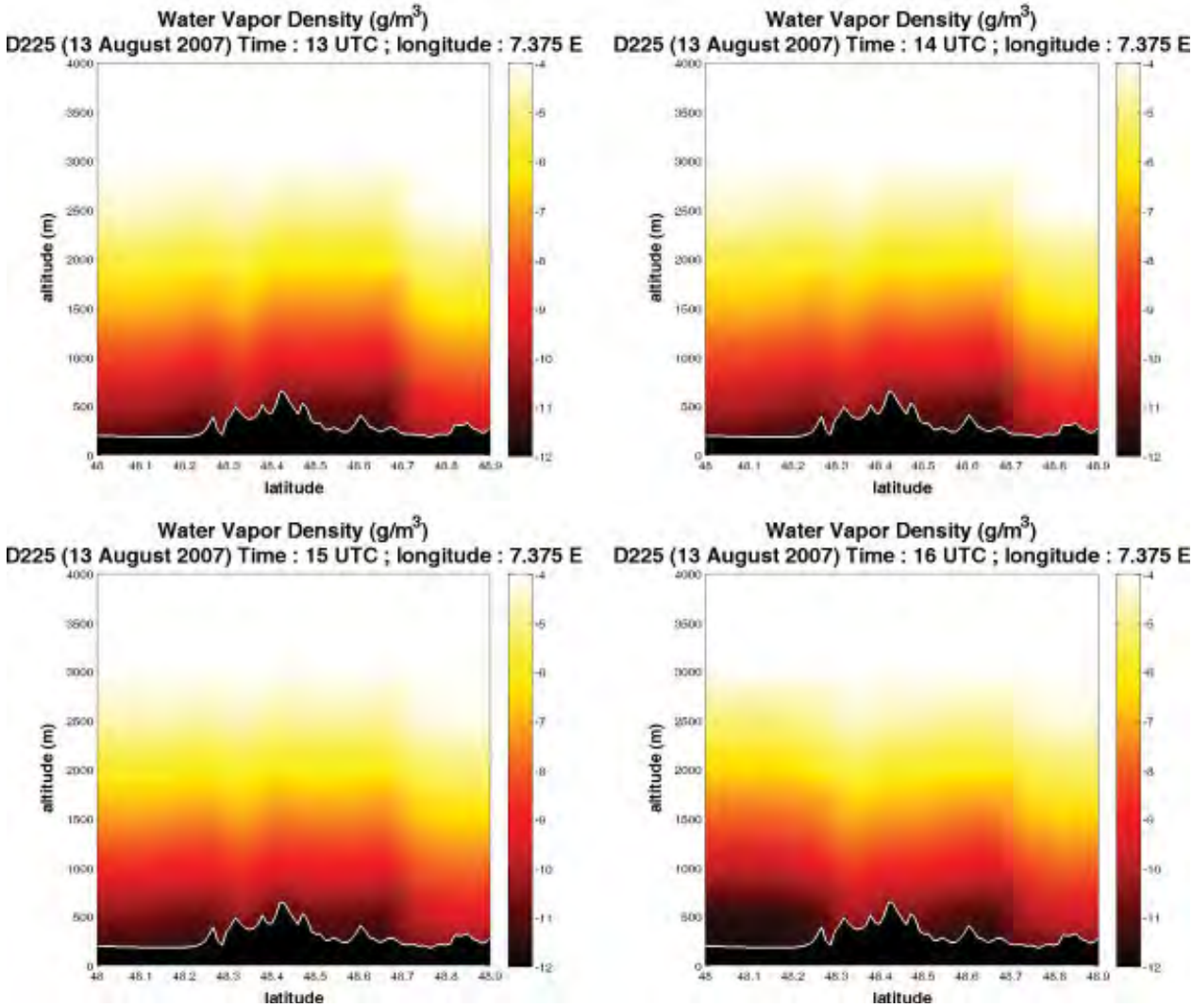

Figure 17. GPS tomography vertical water vapour density cross-sections at constant longitude $7.34^{\circ} \mathrm{E}$ from $11: 00$ to $16: 00$ UTC on August 13 2007 (IOP 15b). The water vapour density scale goes from 4 to $12 \mathrm{~g} \mathrm{~m}^{3}$ (from white to black). This figure is available in colour online at wileyonlinelibrary.com/journal/qj

the different convection initiation spots, almost exclusively on the lee side of the Vosges, and the corresponding duration of the cell tracks extending well across the Rhine Valley offer a quite different pattern from the 12 August situation (Hagen et al., 2011, give further details). Considering now the corresponding water vapour density fields, the horizontal distribution at the $1000 \mathrm{~m}$ level, shown in Figure 15, indicates no specific accumulation towards the mountain ridges but relatively high water vapour values in the Rhine valley instead and reinforcement of the water vapour density at the foothills of the Vosges at those areas and times when convection was documented by POLDIRAD. This is the case at 1200 and 1300 UTC along the northeast side of the Vosges orography. Furthermore, by 1500 and 1600 UTC, there is a marked increase of water vapour at the exit of one of the central Vosges mountain valleys, associated with the generation of a strong cell identified in the south of the POLDIRAD field of view at 1630 UTC. To better illustrate these findings, Figure 16 shows two series of vertical crosssections at constant latitudes. The first one at $48.19^{\circ} \mathrm{N}$ spans the time range from 1200 to 1400 UTC and passes through the cells observed on the north of the Vosges mountain range. Besides high values of water vapour in the Rhine Valley and along the western slopes of the Black Forest, it shows a local burst of water vapour at the foot of the Vosges Mountains at 1300 UTC, corresponding to the precipitation cells monitored. Likewise, the second series of vertical cross-sections at $48.41^{\circ} \mathrm{N}$ spans the time range from 1500 to 1700 UTC and passes through the cell observed in the southern domain of POLDIRAD in Figure 14. In this case, the strong water vapour outflow associated with the convective cell initiation corresponds to water vapour advection above the mountain ridge onto the lee side down along mountain valley. Also quite interesting is Figure 17, where we present the vertical cross-sections at constant longitude spanning 1100 to 1600 UTC and passing along the 
Vosges front ranges. Looking at the first three times (1100 to 1300 UTC), we find a strong evidence of water vapour convergence at the location of a small hill near $48.5^{\circ} \mathrm{N}$, where the strong cell visible at 1300 UTC with POLDIRAD develops. Indeed, from 1100 to 1200 UTC, water vapour levels increase significantly on both sides of the central hill but by 1300 UTC water vapour has converged on that hill where convective initiation takes place. Later, the strong outflow leading to the large convective cell initiation in the south of POLDIRAD field of view is also well identified with a major increase of water vapour density over the lowest levels of the atmosphere around $48^{\circ} \mathrm{N}$.

\section{Concluding remarks and future work}

In this work, we have considered the water vapour field evolution during various precipitation and convective initiation situations monitored during the COPS campaign. We have tried to gain new insights into the role of water vapour in the life cycle of precipitation systems. To do so, we have looked at the water vapour field patterns and behaviour as a function of orography-dependant convective initiation, i.e. ridge or lee-side convection, as well as a function of background synoptic conditions for larger-scale systems.

First, for ridge convection, it is necessary to get significant water vapour accumulation over the crests of the mountains as a precursor to convection onset. This implies that the synoptic wind is not strong enough to carry the water vapour across the range, or that local conditions or singular orographic features favour water vapour blocking and accumulation over the crest. Then, the water vapour acts as a fuel for the convective initiation or regeneration over the mountain ridge. On the contrary, when the water vapour does not stagnate over the mountains but passes the ridge to flow down the main orography, the resulting valley flows are prone to generate lee-side convection when they encounter a small hill and/or some converging flow coming from the warmer plains in the lowest layers of the atmosphere. This combined effect probably creates a significant lifting of high water vapour air and triggers convection.

Second, we have noticed an interesting feature where water vapour seemed to decrease singularly some time before the onset of precipitation or precipitation reinforcement. One hypothesis is that water vapour has been transformed into liquid water through the condensation processes that occur within the convection, meaning that water vapour has given way to cloud formation. Of course, further detailed studies with more measurements are needed in order to confirm the hypothesis.

Finally, we have also noted contrasting behaviour of the water vapour field associated with large-scale precipitation systems. When there is a large and established synoptic-scale frontal passage, the water vapour field appears in phase with the frontal system; the maximum water vapour lies under the front where the air is saturated by rain. However, in the case of a front with low-intensity precipitation, water vapour depletion appears in those spots where the convective cells develop, imbedded in the larger system. That seems to indicate that the cell actually feeds on the underlying water vapour. That assumption is further confirmed by the fact that the convective front 'trails' the water vapour field and develops preferentially in those areas where the water vapour densities are the highest.
At this stage, the work performed here has been essentially qualitative, but we feel that it has proven useful in pointing to very interesting mechanisms that link water vapour distribution and evolution to the precipitating system dynamics and behaviour. Nonetheless, these hypotheses need to be further addressed to draw definite conclusions. This is the object of currently ongoing studies.

Another aspect of this work has also been to test GPS tomography for water vapour field retrieval using only GPS and surface data. The results obtained are quite reasonable and allow meaningful interpretation, in particular in the part of the domain where the GPS station density is the highest to allow higher resolution of the water vapour density field. However, by using only GPS data, the vertical structure of the water vapour field is somewhat reduced unless GPS stations are close enough to form a dense network where multiple rays can cross within individual voxels. Hence, now that we are confident in the GPS tomography method to retrieve $3 \mathrm{D}$ water vapour fields, we plan to improve the current analysis scheme by enhancing the algorithm so that measured profiles of water vapour density within the COPS domain can be accounted for during the inversion initialisation step. This should prove useful in order to achieve better vertical structure in the tomographic results and avoid the vertical dilution of the GPS signal.

Furthermore, we plan to reprocess the periods of interest with higher resolution both in space (especially in the vertical for levels where multiple rays can cross within individual voxels) and time (down to $20 \mathrm{~min}$ ) in order to refine our comparisons with the radar observations in the core of the COPS domain where the GPS station network is sufficiently dense. This will allow us to further study some these events where we can relate the convective initiation to fine orographic features such as hills within the exit of mountain valleys.

Finally, we will also increase the scope of the present analyses by using other types of observation and supporting atmospheric variables, such as the low-level wind from dual Doppler radar analysis and VERA analysis, and groundbased and airborne lidar measurements. Likewise, we will compare our measurements and field retrievals with model output as a way to both validate the corresponding results and to investigate in detail the processes and controlling factors of the life cycle of precipitation systems.

\section{Acknowledgements}

The lead author would like to thank the anonymous reviewers for their precise and constructive comments and, in particular, for a series of thought-provoking questions and suggestions which, without a doubt, have significantly contributed to the improvement of the article and have also initiated further investigations now in progress.

The COPS campaign implementation and the instrument participation (radars and GPS in this instance) were made possible through the financial support of the DFG Priority Programme 1167 in Germany, and ANR (grant ANR-06-BLAN-0018-04: COPS/France) and CNRS/INSU (LEFE/IDAO program) in France.

\section{References}

Aoshima F, Behrendt A, Bauer H-S, Wulfmeyer V. 2008. Statistics of convection initiation by use of Meteosat rapid scan data during the 
Convection and Orographically-induced Precipitation Study (COPS). Meteorol. Z. 17: 921-930.

Barthlott C, Burton R, Kirshbaum D, Hanley K, Richard E, Chaboureau JP, Trentmann J, Kern B, Bauer H-S, Schwitalla T, Keil C, Seity Y, Gadian A, Blyth A, Mobbs S, Flamant C, Handwerker J. 2011. Initiation of deep convection at marginal instability in an ensemble of mesoscale models: a case-study from COPS. Q. J. R. Meteorol. Soc. 137(S1): 118-136, DOI: $10.1002 / q j .707$.

Behrendt A, Pal S, Aoshima F, Bender M, Blyth A, Corsmeier U, Cuesta I, Dick G, Dorninger M, Flamant C, Di Girolamo P, Gorgas T, Huang Y, Kalthoff N, Khodayar S, Mannstein H, Träumner K, Wieser A, Wulfmeyer V. 2011. Observation of convection initiation processes with a suite of state-of-the-art research instruments during COPS IOP 8b. Q. J. R. Meteorol. Soc. 137(S1): 81-100, DOI: 10.1002/qj.758.

Bender M, Dick G, Wickert J, Schmidt T, Song S, Gendt G, Ge M, Rothacher M. 2008. Validation of GPS slant delays using water vapour radiometers and weather models. Meteorol. Z. 17: 807-812.

Bennett LJ, Blyth AM, Burton RR, Gadian AM, Weckwerth TM, Behrendt A, Di Girolamo P, Dorninger M, Lock S-J, Smith VH, Mobbs SD. 2011. Initiation of convection over the Black Forest mountains during COPS IOP15a. Q. J. R. Meteorol. Soc. 137(S1): 176-189, DOI: $10.1002 / q j .760$.

Bevis M, Businger S, Herring TA, Rocken C, Anthes RA, Ware RH. 1992. GPS meteorology: Remote sensing of atmospheric water vapour using the Global Positioning System. J. Geophys. Res. 103: 15787-15801.

Bevis M, Businger S, Chiswell SR, Herring TA, Anthes RA, Rocken C, Ware RH. 1994. GPS meteorology: Mapping zenith wet delay onto precipitable water. J. Appl. Meteorol. 33: 379-386.

Boehm J, Niell A, Tregoning P, Schuh H. 2006. Global Mapping Function (GMF): A new empirical mapping function based on numerical weather model data. Geophys.Res. Lett. 33: L07304, DOI: 10.1029/2005GL025546.

Braun J, Rocken C, Liliegren J. 2003. Comparisons of line-of-sight water vapour observations using the Global Positioning System and a pointing microwave radiometer. J.Atmos. Oceanic Technol. 20: 606-612.

Businger S, Chiswell SR, Bevis M, Duan J, Anthes RA, Rocken C, Ware RH, Exner M, VanHove T, Solheim F. 1996. The promise of GPS in atmospheric monitoring. Bull. Amer. Meteorol. Soc. 77: 5-18.

Champollion C, Masson F, Bouin M-N, Walpersdorf A, Doerflinger E, Bock O, Van Baelen J. 2005. GPS water vapour tomography: First results from the ESCOMPTE field experiment. Atmos. Res. 74: 253-274.

Champollion C, Flamant C, Bock O, Masson F, Turner DD, Weckwerth TM. 2009. Mesoscale GPS tomography applied to the 12 June 2002 convective initiation event of IHOP_2002. Q. J. R. Meteorol. Soc. 135: 645-662, DOI: 10.1002/qj.386.

Collier CG, Davies F, Davis J, Pearson G, Hagen M. 2008. 'Doppler radar and lidar observations of a thunderstorm outflow'. In Proceedings of the fifth European Conference on Radar in Meteorology and Hydrology, Helsinki, Finland, 30 June-4 July 2008.

Corsmeier U, Kalthoff N, Barthlott C, Behrendt A, Di Girolamo P, Dorninger M, Handwerker J, Kottmeier C, Mahlke H, Mobbs SD, Norton EG, Wickert J, Wulfmeyer V. 2011. Processes driving deep convection over complex terrain: A multi-scale analysis of observations from COPS IOP 9c. Q. J. R. Meteorol. Soc. 137(S1): 137-155, DOI: $10.1002 / q j .754$.

Duan J, Bevis M, Fang P, Bock Y, Chiswell SR, Businger S, Rocken C, Solheim F, VanHove T, Ware R, McClusky S, Herring TA, King RW. 1996. GPS meteorology: Direct estimation of the absolute value of precipitable water. J. Appl. Meteorol. 35: 830-838.

Emardson TR, Derks HJP. 1999. On the relation between the wet delay and the integrated precipitable water vapour in the European atmosphere. Meteorol. Appl. 6: 1-12.

Flores A, Rius A, Ruffini G. 2000. 4D tropospheric tomography using GPS slant wet delays. Ann. Geophys. 18: 223-224.

Flores A, Vilà-Guerau de Arellano J, Gradinarsky L, Rius A. 2001. Tomography of the lower troposphere using a small dense network of GPS receivers. IEEE Trans. Geosci.Remote Sensing 39: 439-447.

Gendt G, Dick G, Rius A, Sedo P. 2001. Comparison of software and techniques for water vapour estimation using German near-real-time GPS data. Phys. Chem.Earth A 26: 417-420.

Gendt G, Dick G, Reigber C, Tomassini M, Liu Y, Ramatschi M. 2004. Near-real-time GPS water vapour monitoring for numerical weather prediction in Germany. J. Meteorol. Soc. Japan 82: 361-370.

Gradinarsky LP, Jarlemark P. 2004. Ground-based GPS tomography of water vapour: Analysis of simulated and real data. J. Meteorol. Soc. Japan 82: 551-560.

Ha S-Y, Kuo Y-H, Guo Y-R. 2003. Variational assimilation of slantpath wet delay measurements from a hypothetical ground-based GPS network. Part I: Comparison with precipitable water assimilation Mon. Weather Rev. 131: 2635-2655.

Hagen M, van Baelen J, Richard E. 2011. Influence of the wind profile on the initiation of convection in mountainous terrain. Q. J. R. Meteorol. Soc. 137(S1): 224-235, DOI: 10.1002/qj.784.

Kottmeier C, Kalthoff N, Barthlott C, Corsmeier U, Van Baelen J, Behrendt A, Behrendt R, Blyth A, Coulter R, Crewell S, Di Giromalo P, Dorninger M, Flamant C, Foken T, Hagen M, Hauck C, Höller H, Konow H, Kunz M, Mahlke H, Mobbs SD, Richard E, Steinacker R, Weckwerth TM, Wieser A, Wulfmeyer V. 2008. Mechanisms initiating deep convection over complex terrain during COPS. Meteorol. Z. 17: 931-948.

Liljegren JC, Lesht BM, VanHove T, Rocken C. 1999. 'A comparison of integrated water vapor from microwave radiometer, balloon-borne sounding system, and global positionnng system'. Ninth ARM Science Team Meeting, San Antonio, TX, 22-26 March 1999.

Liu H, Xue M. 2006. Retrieval of moisture from slant-path water vapour observations of a hypothetical GPS network using a three-dimensional variational scheme with anisotropic background error. Mon. Weather Rev. 134: 933-949.

MacDonald A, Xie Y, Ware R. 2002. Diagnosis of three-dimensional water vapour using slant observations from a GPS network. Mon. Weather Rev. 130: 386-397.

McClatchey RA, Fenn RW, Selby JEA, Volz FE, Garing JS. 1972. 'Optical properties of the atmosphere'. Environmental Research Paper AFCRL72-0497, Air Force Cambridge Research Lab: Hanscom, Mass, USA.

Menke W. 1989. Geophysical Data Analysis: Discrete Inverse Theory. Academic Press: London.

Niell AE. 1996. Global mapping functions for the atmosphere delay at radio wavelengths. J. Geophys. Res. 101: 3227-3246.

Planche C, Wobrock W, Flossmann AI, Tridon F, Van Baelen J, Pointin Y, Hagen M. 2010. The influence of aerosol particle number and hygroscopicity on the evolution of convective cloud systems and their precipitation: A numerical study based on the COPS observations on 12 August 2007. Atmos. Res. 98: 40-56, DOI: 10.1016/j.atmosres.2010.05.003.

Reverdy M. 2008. 'Estimation des paramètres atmosphériques par GPS: analyse de la variabilité spatio-temporelle de la vapeur d'eau'. Thesis 598, Université Blaise Pascal: Clermont-Ferrand, France.

Reverdy M, Van Baelen J, Walpersdorf A, Dick G, Hagen M, Richard E. 2009. Water vapour field retrieval with tomography software. Ann. Meteorol. 44: 144-145. Deutscher Wetterdienst: Offenbach. http://www.pa.op.dlr.de/icam2009/extabs.

Richard E, Flamant C, Bouttier F, Van Baelen J, Champollion C, Hagen M, Cuesta J, Bosser P, Pigeon G, Argence S, Arnault J, Brousseau P, Seity Y, Chaboureau J-P, Limnaios P, Masson F, Pointin Y, Di Girolamo P, Wulfmeyer V. 2009. La campagne COPS: Initiation et cycle de vie de la convection en région montagneuse. $L a$ Météorologie 64: 32-42.

Richard E, Chaboureau J-P, Flamant C, Champollion C, Hagen M, Schmidt K, Kiemle C, Corsmeier C, Barthlott C. 2011. Forecasting summer convection over the Black Forest: a case-study from the Convective and Orographically-induced Precipitation Study (COPS) experiment. Q. J. R. Meteorol. Soc. 137(S1): 101-117, DOI: 10.1002/qj.710.

Saastamoinen J. 1972. Atmospheric correction for the troposphere and stratosphere in radio ranging of satellites. In The use of Artificial Satellites for Geodesy. Geophys. Monogr. 15: 247-251. Amer. Geophys. Union: Washington DC.

Schroth AC, Chandra MS, Mesichner PF. 1988. A C-band coherent polarimetric radar for propagation and cloud physics research. $J$. Atmos. Oceanic Technol. 5: 803-822.

Schwitalla T, Bauer H-S, Wulfmeyer V. 2011. High-resolution simulation over central Europe using GPS-ZTD observations with WRF 3D-Var: A case-study of COPS IOP9c. Q. J. R. Meteorol. Soc. 137(S1): 156-175. Solheim F, Vivekanandan J, Ware R, Rocken C. 1999. Propagation delays induced in GPS signals by dry air, water vapour, hydrometeors and other atmospheric particulates. J. Geophys Res. 104(D8): 9663-9670.

Steinacker R, Ratheiser M, Bica B, Chimani B, Dorninger M, Gepp W, Lotteraner C, Schneider S, Tschannett S. 2006. A mesoscale data analysis and downscaling method over complex terrain. Mon. Weather Rev. 134: 2758-2771.

Tarantola A. 2005. Inverse problem theory and methods for model parameter estimation. SIAM: Philadelphia, USA.

Tregoning P, Boers R, O'Brien D, Hendy M. 1998. Accuracy of absolute precipitable water vapour estimates from GPS observations. J. Geophys. Res. 103: 28701-28710.

Van Baelen J, Penide G. 2009. Study of water vapour vertical variability and possible cloud formation with a small network of GPS stations. Geophys. Res. Lett. 36: L02804, DOI: 10.1029/2008GL036148. 
Van Baelen J, Aubagnac J-P, Dabas A. 2005. Comparison of nearreal-time estimates of integrated water vapour derived with GPS, radiosondes, and microwave radiometer. J. Atmos. Oceanic Technol. 22: $201-210$.

Wang J, Zhang L, Dai A, Van Hove T, Van Baelen J. 2007. A nearglobal two-hourly data set of atmospheric precipitable water from ground-based GPS measurements. J. Geophys. Res. 112: D11107, DOI: 10.1029/2006JD007529.

Ware R, Alber C, Rocken C, Solheim F. 1997. Sensing integrated water vapour along GPS ray paths. Geophys. Res. Lett. 24: 417-420.

Wulfmeyer V, Behrendt A, Bauer H-S, Kottmeier C, Corsmeier U, Blyth A, Craig G, Schumann U, Hagen M, Crewell S, Di Girolamo P, Flamant C, Miller M, Montani A, Mobbs SD, Richard E, Rotach MW, Arpagaus M, Russchenberg H, Schlüssel P, König M, Gärtner V, Steinacker R, Dorninger M, Turner DD, Weckwerth TM, Hense A Simmer C. 2008. The Convective and Orographically-induced Precipitation Study: A research and development project of the World Weather Research Program for improving quantitative precipitation forecasting in low-mountain regions. Bull. Amer. Meteorol. Soc. 89: $1477-1486$.
Wulfmeyer V, Behrendt A, Kottmeier C, Corsmeier U, Barthlott C, Craig G, Hagen M, Althausen D, Aoshima F, Arpagaus M, Bauer HS, Bennett L, Blyth A, Brandau C, Champollion C, Crewell S, Dick G, Di Girolamo P, Dorninger M, Dufournet Y, Eigenmann R, Engelmann R, Flamant C, Foken T, Gorgas T, Grzeschik M, Peters G, Handwerker J, Hauck C, Höller H, Junkermann W, Kalthoff N, Kiemle C, Klink S, König M, Krauss L, Long C, Madonna F, Mobbs SD, Neininger B, Pal S, Peters G, Pigeon G, Richard E, Rotach MW, Russchenberg H, Schwitalla T, Smith V, Steinacker R, Trentmann J, Turner DD, van Baelen J, Vogt S, Volkert H, Weckwerth T, Wernli H, Wieser A, Wirth M. 2011. The Convective and Orographically-induced Precipitation Study (COPS): the scientific strategy, the field phase, and research highlights. Q. J. R. Meteorol. Soc. 137(S1): 3-30, DOI: 10.1002/qj.752.

Zumberge JF, Heflin MB, Jefferson DC, Watkins MM, Webb FH. 1997. Precise point positioning for the efficient and robust analysis of GPS data from large networks. J. Geophys. Res. 102(B3): 5005-5018.

Zus F, Grzeschik M, Bauer H-S, Wulfmeyer V. 2008. Design and optimization of the IPM GPS slant path 4DVAR system. Meteorol. Z. 17: $867-885$. 